\title{
USOS DO RELEVO, DAS ÁGUAS E DA PESCA NA TRAJETÓRIA HISTÓRICA DE COMUNIDADES TRADICIONAIS CAIÇARAS EM TERRITÓRIOS NORMATIZADOS COMO UNIDAADE DE CONSERVAÇÃO (ILHA DO CARDOSO, SP)
}

Uses of relief, waters and fishing by tradicional caiçaras communities in territories regulated as a conservation unit (Ilha do Cardoso, SP, Brasil)

Pedro Michelutti Cheliz

Geógrafo e Geólogo, vinculado ao Departamento de Geografia do Instituto de Geociências da UNICAMP, e ao Instituto de Pesquisas Cananéia (IPEC)

Pedro.michelutti@gmail.com

Juliana Greco Yamaoka

Turismóloga, Programa de pós-Graduação em Meio Ambiente e Desenvolvimento da UFPR julianagreco82@gmail.com

Willian Gomes Cubas

Engenheiro de Pesca

wiliangcubas@gmail.com

\section{Juliana Lourenço Gonçalves}

Oceanógrafa, Universidad de lá República, Uruguai

Ju.logoncalves@gmail.com

Recebido: 03.12.2021

Aceito: 08.02.2022

\section{Resumo}

Buscando contribuir para discussões sobre interações entre comunidades tradicionais e quadros naturais da paisagem, caracterizou-se alterações ao longo do tempo do uso das unidades de relevo, das terras e das águas nos territórios e nas territorialidades de comunidades caiçaras da llha do Cardoso. Elencou-se três diferentes padrões de mediação com as terras emersas e águas nas territorialidades das comunidades caiçaras locais, cada qual deles associados a diferentes conjuntos de técnicas de pesca artesanais predominantes. Apontou-se oscilação dos quadros naturais tomados como preferenciais para instalação das comunidades e aumento da centralidade da pesca nos modos de vida caiçaras após a normatização de seus territórios tradicionais e da própria llha como uma unidade de conservação de proteção integral em meados do século $X X$. Caracterizou-se posteriores flutuações ao longo do tempo da centralidade e práticas da pesca em cada um dos conjuntos de territórios tradicionais locais, ligadas em parte ora ao endurecimento, ora ao abrandamento das restrições legais de uso do território vindas das modificações dos planos de manejo da unidade de conservação.

Palavras-chave: Pesca Artesanal; História Ambiental; Etnogeomorfologia; Cananéia; Turismo. 


\begin{abstract}
Seeking to contribute to discussions on interfaces between traditional communities and natural landscapes, were characterized changes over time in the use of relief units, land and water in the territories and territorialities of caiçara communities on Ilha do Cardoso. Three different mediation patterns with the emerged lands and waters in the territorialities of the local communities were described. There was characterized an oscillation of the natural landscapes taken as preferential for the installation of local communities and an increase in the centrality of fishing in the caiçaras ways of life after the standardization of their traditional territories and the island itself as a conservation unit in the mid-20th century. Subsequent fluctuations were identified over time in the centrality of fishing in each of the traditional local territories, partly linked at times to hardening, sometimes to the easing of legal restrictions on the use of the territory due to changes in the management plans of the conservation unit.
\end{abstract}

Keywords: Traditional Fishing; Environmental History; Geomorphology; Cananéia, Tourism.

\title{
1. INTRODUÇÃO
}

As interações tardias entre comunidades tradicionais (ZEDEÑO, 1997 e 2008) que permaneceram longamente relativamente isoladas e autocentradas com um conjunto externo que se modificou profundamente e se incorporou mais cedo ao meio técnico atualmente predominante vem longamente sendo tema de discussão (BASTIDE, 1964; CANDIDO, 1965; SANTOS, 2003). No litoral sul do Estado de São Paulo, tem-se exemplo de uma área em que tais interfaces se fazem presentes, e que permite a realização de um estudo de detalhe sobre o tema. Trata-se da llha do Cardoso (figuras 1 e 2), de cuja moldura colossal de altos picos serranos desmembra-se um sem fim de cumeadas e vales florestados, seccionados ou sucedidos por inúmeras discretas reentrâncias, estuários, baias e planícies tomadas como refúgios por núcleos familiares de agricultores e pescadores que ali vivem desde, ao menos, o tempo do Império. Integrando, assim, os territórios das populações tradicionais caiçaras, apontadas por Diegues (2005) como dispersas entre o litoral do Rio de Janeiro e Paraná.

A dinâmica dada por certo isolamento local no histórico de ocupação que longamente pautou a Ilha, inicialmente ligada ao esgotamento dos ciclos econômicos regionais (perda de vias de ligação marítima por assoreamento do principal porto do litoral sul de São Paulo - Iguape) e posteriormente reforçada pela transformação em Unidade de Conservação, bem ilustra a questão do chamado "desenvolvimento desigual" da Região Lagunar de Cananéia-Iguape e do próprio Vale do Ribeira (BRAGA, 1999). Para pouco além das cabeceiras mais distanciadas do Rio Ribeira, nos grandes centros urbanos do sul-sudeste brasileiro que se erguem nos planaltos que circundam o Vale, 
promoveu-se sobretudo a partir da segunda metade do século $X X$ intensas transmutações do espaço habitado. Concentrou-se ali os esforços desenfreados de urbanização e industrialização tardia no contexto brasileiro. Vias de ligação entre os centros urbanos em profusão (tais como as áreas metropolitanas de São Paulo e Curitiba) cortavam a região histórica do Vale, e deram origem a intenso fluxo motorizado de pessoas, mercadorias e materiais de suporte ao complexo urbano-industrial entre as metrópoles paulistana e curitibana (SANTOS, 2003).

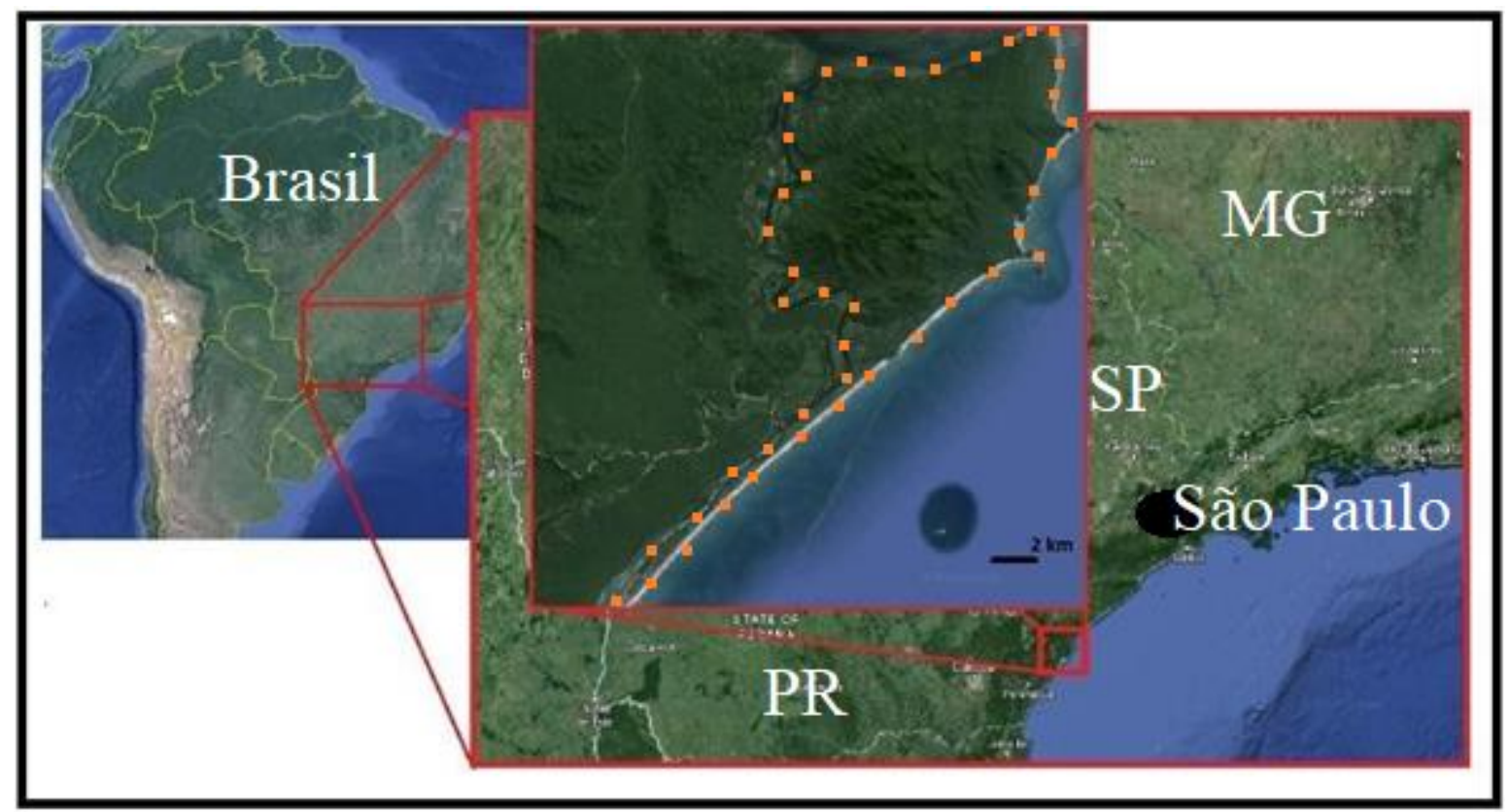

Figura 1 - localização da Ilha do Cardoso (realçada por pontilhado laranja).

Fonte: adaptado de Cheliz (2015).

A despeito destas intensas transformações dos entornos, a fachada litorânea do Vale e a própria llha permaneceram, por longo tempo, relativamente à margem de tais processos, conservando padrões de mediação entre modos de vida tradicionais com os quadros naturais que eram intensamente alterados em locais não tão distantes dali. Nos grandes centros urbanos em frenética expansão além das cabeceiras do Rio Ribeira, legiões de homens e mulheres chegados às pressas de diversos recantos do país erguiam novos mundos de aço, maquinas, concreto e eletricidade. Na Ilha por sua vez, grupos de pescadores remanescentes (figura 2B) permaneciam nascendo e crescendo rentes as sombras das mesmas escarpas florestadas (figura 2A) que seus avós conheceram. Seguiam singrando lentamente os rios e mares em seus discretos barcos e canoas, e regulando seus dias e noites pela passagem das estações, das marés e das luas (GADELHA, 2008; CHELIZ, 2015). A vida e seus caminhos tinham seus limites dados pelos bordos das clareiras em que erguiam suas vilas e sítios, e pelas águas que batiam 
suas praias e costões, onde o que ocorria além delas chegava ali apenas como mais um murmúrio marginal em meio à arrebentação das ondas noturnas.
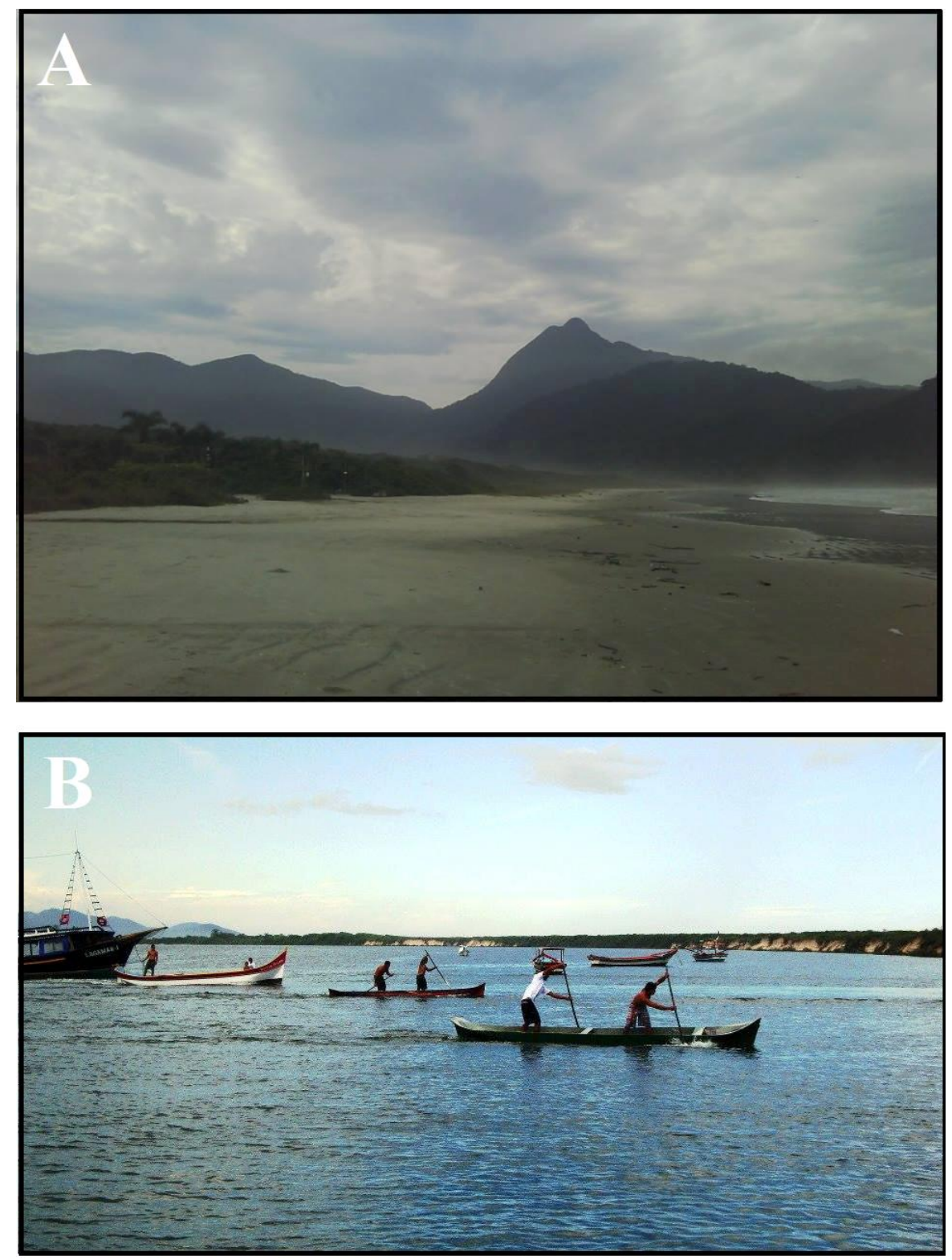

Figura 2 - A: representação dos principais quadros naturais com os quais interagem as comunidades que vivem na llha do Cardoso - em primeiro plano transição entre terras emersas e águas circundantes, com Planícies Diversificadas em segundo plano, e Serranias em terceiro. B: moradores da llha do Cardoso, da comunidade Enseada da Baleia (segmento sul da llha), circulando em canoas próximos aos limites entre terras emersas e águas circundantes, por ocasião da prova de corrida de canoas na festa de padroeiro.

Fonte: adaptado a partir de fotografias de Cheliz (2015) e Yamaoka (2016).

Mundo em parte longamente fechado em si abre-se lentamente. Possibilidades como as advindas de flexibilizações na regulação da política de conservação do Parque Estadual da Ilha do Cardoso (SILVA, 2014) no início do século XXI passam a modificar o quadro local, bem como construção de pontes, estradas e posterior duplicação das mesmas, facilitando acesso da porção insular do município de Cananéia (SP) ao continente, ampliando contato e circulação de atores originados dos grandes centros 
urbanos do Centro-Sul do Brasil em meio aos territórios locais (CHELIZ, 2015). Territórios estes que - face apresentarem simultaneamente elevada preservação ambiental (em contraste com os intensamente poluídos grandes centros metropolitanos que circundam o Vale do Ribeira), correlata beleza cênica de suas paisagens litorâneas e proximidade relativa de populosas cidades (e.g - Curitiba e São Paulo) - passam a serem visados de diferentes maneiras por tais atores externos.

Diante desse contexto, o presente trabalho busca realizar uma discussão comparativa sobre como as territorialidades - tal como definidas por Zedeño (1997 e 2008) - das comunidades tradicionais da llha do Cardoso se deram nos tempos: 1intervalo prévio a conversão do território da llha em unidade de conservação e parque estadual (anterior a 1962); 2- ao tempo de maior isolamento e restrições de práticas de ocupação ligados a nova normatização territorial (entre 1962 e 1998) com a decretação da llha como uma unidade de conservação; 3- ao tempo de abrandamento de algumas destas restrições por ocasião de mudanças e flexibilizações do plano de manejo do Parque (posterior a 1998), e ampliação da circulação local de pessoas externas à ilha (notadamente via atividades de turismo). Buscou-se realizar tal abordagem com ênfase em discutir como o relevo e as águas da llha do Cardoso foram incorporadas nas territorialidades e modos de vida das comunidades caiçaras locais (ZEDEÑO, 1997 e 2008) em cada um destes diferentes cenários temporais. Procura-se discutir sobre como as restrições advindas da conversão em unidade de conservação (e posterior abrandamento das mesmas) teriam contribuído para adaptações, modificações e permanências das unidades de relevo favorecidas para uso pelas comunidades locais, bem como a adequações nas maneiras como estabelecem mediações com as terras e águas da llha e entornos.

\section{MÉTODOS}

O artigo buscou realizar uma compilação e comparação entre dois conjuntos distintos de informações sobre a llha do Cardoso: 1- caracterização dos quadros físiconaturais da Ilha, 2- caracterização da ocupação humana caiçara. Simultaneamente, o trabalho buscou realizar novas entrevistas semi-estruturadas e atividades de imersão junto as comunidades da llha do Cardoso para aprofundar o segundo conjunto de informações mencionadas. $\mathrm{Na}$ discussão da interface desses dois conjuntos de informações, buscou-se estabelecer um diálogo com a concepção de território como objeto agregado (terra + recursos naturais + modificações humanas) e de territorialidade 
(soma de ações e emoções numa área específica, com ênfase na influência, controle e acesso) de Zedeño (1997 e 2008).

A compilação de informações ligadas aos quadros naturais da ilha procurou elencar as principais características das terras emersas da llha e das águas adjacentes, com ênfase para atributos de relevo e a caracterização geomorfológica da llha realizada por Cheliz (2015). Buscando, assim, estabelecer um diálogo com um dos componentes do território que Zedeño (2008) define como "terra" (terrenos, sobre os quais apresentam-se "recursos naturais"). Usa-se no presente artigo a definição de quadros naturais como os componentes bióticos e não bióticos não antrópicos do meio que não foram alvos diretamente do trabalho direto e intencional de grupos humanos ao longo da área de estudo nas últimas décadas. Buscou-se, assim, caracterizar diferentes potencialidades (elementos tidos pelos grupos humanos como favoráveis ao desenvolvimento de seus modos de vida) e restrições (elementos dos quadros naturais tidos como desfavoráveis aos mesmos modos de vida) associadas às unidades de relevo locais e águas circundantes para os caminhos caiçaras (DIEGUES, 2005) de mediações com os quadros naturais.

A compilação de informações referentes aos modos de vida caiçaras da llha e de suas estratégias de sobrevivência em diversas etapas de normatização legal do território da llha, por sua vez, foi tomada com um misto de revisão bibliográfica de trabalhos anteriores (e.g - MENDONÇA, 1999; GADELHA, 2008; CARVALHO e SHCMITT, 2012; MARINHO, 2013; SILVA, 2014; HAYAMA \& CARDOSO, 2018) e apresentação do sumário dos resultados de novas informações compiladas por meio dos procedimentos descritos nos novos estudos de Cubas (2018), Yamaoka (2019) e Gonçalves (2021). Buscou-se, assim, estabelecer um diálogo com a concepção do elemento de "modificações humanas" da definição de território de Zedeño (1997 e 2008), bem como estabelecer um diálogo com a concepção de territorialidade da citada autora.

Dentre as informações levantadas para discutir as modificações humanas do território, ressaltamos a realização de 25 novas entrevistas semi-estruturadas com moradores das diversas vilas caiçaras da llha do Cardoso, pedindo nas supracitadas entrevistas que compartilhassem suas impressões sobre: 1 - Quais tipos de distinções que os próprios moradores realizam em relação ao quadro natural das terras emersas e águas dos entornos de suas comunidades, questionando se fazem leituras de áreas com relativas homogeneidades internas quanto a elementos percebidos como favoráveis e desfavoráveis para seus modos de vida; 2- Quais relações que desenvolvem nos seus 
modos de vivência com as áreas apontadas como ligadas a distintas unidades de relevo (Serranias e diferentes tipos de planícies) no mapa geomorfológico efetuado por Cheliz (2015). Por ocasião das entrevistas, foi apresentado aos moradores uma cópia do supracitado mapa, com localização na ilha de cada comunidade. Procurou-se, assim, discutir junto aos moradores se os diferentes conjuntos de unidades da llha distinguidos por Cheliz (2015) eram vistos por eles como ligados a conjuntos relativamente homogêneos de atributos naturais percebidos como favoráveis ou desfavoráveis para seus modos de vida, ou se tratavam de divisões que Ihes pareciam arbitrárias e sem conexão com as relações que estabeleciam com o meio. Nos casos de respostas afirmativas, procurou-se perguntar quais seriam esses atributos favoráveis e desfavoráveis para suas vivências que atribuíam a cada uma destas unidades de relevo, e comparar as respostas com o que foi caracterizado pelo estudo geomorfológico supracitado; 3 - tipos de distinções que estabelecem nas águas dos entornos, questionando-os se identificam segmentos dos rios ou mares adjacentes mais ou menos adequados para atividades importante para suas vidas, como pesca e de transporte, 4 - a importância da pesca para o sustento e manutenção de seus modos de vida, e no estabelecimento de relações com as terras emersas e águas dos entornos em que vivem; 5 - mudanças que eventualmente tenham percebido sobre os temas 1, 2, 3 e 4 ao longo do tempo.

As entrevistas foram feitas com respostas abertas, sem alternativas préestabelecidas, de maneira que se procurou incentivar que os entrevistados discorressem livremente sobre os temas supracitados.

Adicionalmente, buscou-se apresentar as informações advindas das entrevistas intercaladas com outras advindas de observações diretas de atividades locais na Ilha, reproduzidas aqui com as devidas autorizações, derivadas de estadias prolongadas dos dois primeiros autores em algumas das comunidades (e.g - múltiplas estadias que somam mais de um ano nas comunidades do Pereirinha, Marujá e Enseada da Baleia dispersas entre o período de 2013 e 2020 por ocasião de realização de pesquisa de mestrado e doutorado do primeiro autor, e entre 2005 e 2018 nas comunidades do Marujá e Enseada da Baleia por ocasião de atividades profissionais e realização de pesquisa de mestrado por parte da segunda autora). Igualmente, intercalou-se o resultado das entrevistas com observações da llha realizadas pelo terceiro autor, estas originadas de sua vivência como morador tradicional de uma das comunidades locais. Após a conclusão deste artigo, cópias do mesmo foram encaminhados para membros das 
comunidades locais, consultando-os sobre se teriam algum eventual tipo de veto ao conteúdo aqui apresentado.

\section{RESULTADOS E DISCUSSÃO}

\subsection{As terras e as água da Ilha do Cardoso}

Situada no município de Cananéia (litoral sul de São Paulo), a Ilha do Cardoso mostra-se afastada alguns poucos quilômetros do continente, próxima a outras três ilhas (Ilha de Cananéia a norte, Ilha Comprida a nordeste, e Ilha de Superagui a noroeste). Distribui-se em planta de maneira assemelhada a uma grande elipse de cerca de 150 quilômetros quadrados, com seus limites circundados pelas águas que a cercam (Figura 3). Mostrava-se acrescida a sudoeste de um cordão sedimentar estirado de cerca de quinze quilômetros de extensão e área de aproximados 10 quilômetros quadrados, que recentemente (e.g - Agosto de 2018) rompeu-se em dois cordões menores (SOUZA, 2018; CHELIZ et al., 2019; SOUZA et al. 2019), mesclando-se a longa trajetória conhecida de intensas modificações da linha de costa local ao longo do tempo (Figura 4).

A sul encontra-se defronte as linhas de arrebentação do Oceano Atlântico denominado de "Mar de Fora" ou "Mar Revolto", conforme os moradores locais. As águas do "Mar de Fora" são caracterizadas pela ocorrência de ondas que podem superar 2 metros, sendo frequentemente atingidas por intensos vendavais vindos da passagem dos sistemas frontais frios - chamados de "Vento Sul" pelos pescadores da ilha (CHELIZ, 2015). A norte, a llha encontra-se voltada para as águas lagunares da Baia de Trapandé "Mar de Dentro" (associada a águas doces e salobras mais calmas e relativamente poupadas da influência direta das intensas arrebentações de ondas do Oceano Atlântico). O clima é úmido (>2000 mm de precipitação anual) e com temperaturas superiores a 35 graus Celsius no verão, e por vezes inferiores a 15 graus no Inverno.

As bases físico-naturais da llha incluem dois distintos conjuntos (figuras 3 e 4) de quadros de relevo, tal como caracterizados por Cheliz (2015): Serranias e Planícies. As Serranias caracterizam-se por altitudes predominantemente contidas entre 20 e 720 metros acima do nível do mar, com terrenos caracterizados por declives elevados (inclinações predominantes contidas entre 10 e 40 graus de inclinação), marcadas por vales fluviais de inclinações e desníveis verticais locais tão maiores quanto mais elevada a altitude. Mostram-se recobertas por densas florestas sempre-verdes (matas atlânticas), e são associadas a unidades rochosas graníticas e metamórficas diversificadas, e a solos originados de sua alteração. Seus segmentos de menores altimetrias (Baixas Vertentes) 
Caderno de Geografia (2022) v.32, n.68

ISSN 2318-2962

DOI 10.5752/p.2318-2962.2022v32n.68p.73

são caracterizados também por menores declives, e vales menos profundos (dificilmente apresentando desníveis verticais locais maiores do que 120 metros), e os segmentos mais elevados (Altas Vertentes) são ligadas a maiores inclinações do terreno (CHELIZ e OLIVEIRA, 2021).

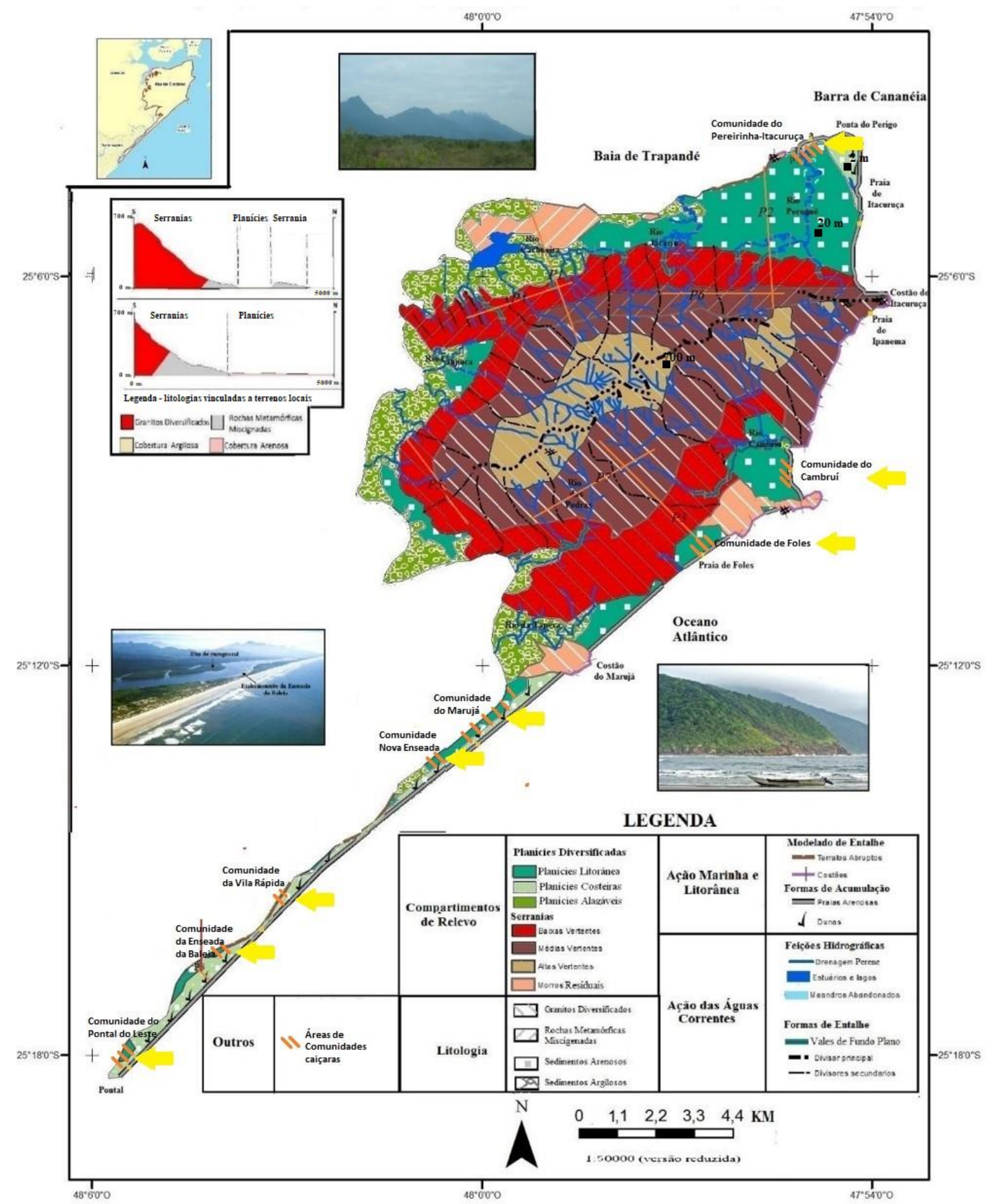

Figura 3 - Composição onde se encontram sobrepostos o mapa geomorfológico da llha do Cardoso do ano de 2013, e a localização das áreas ocupadas pelas comunidades caiçaras locais (destacadas por setas amarelas).

Fonte: adaptado de Cheliz (2015) 

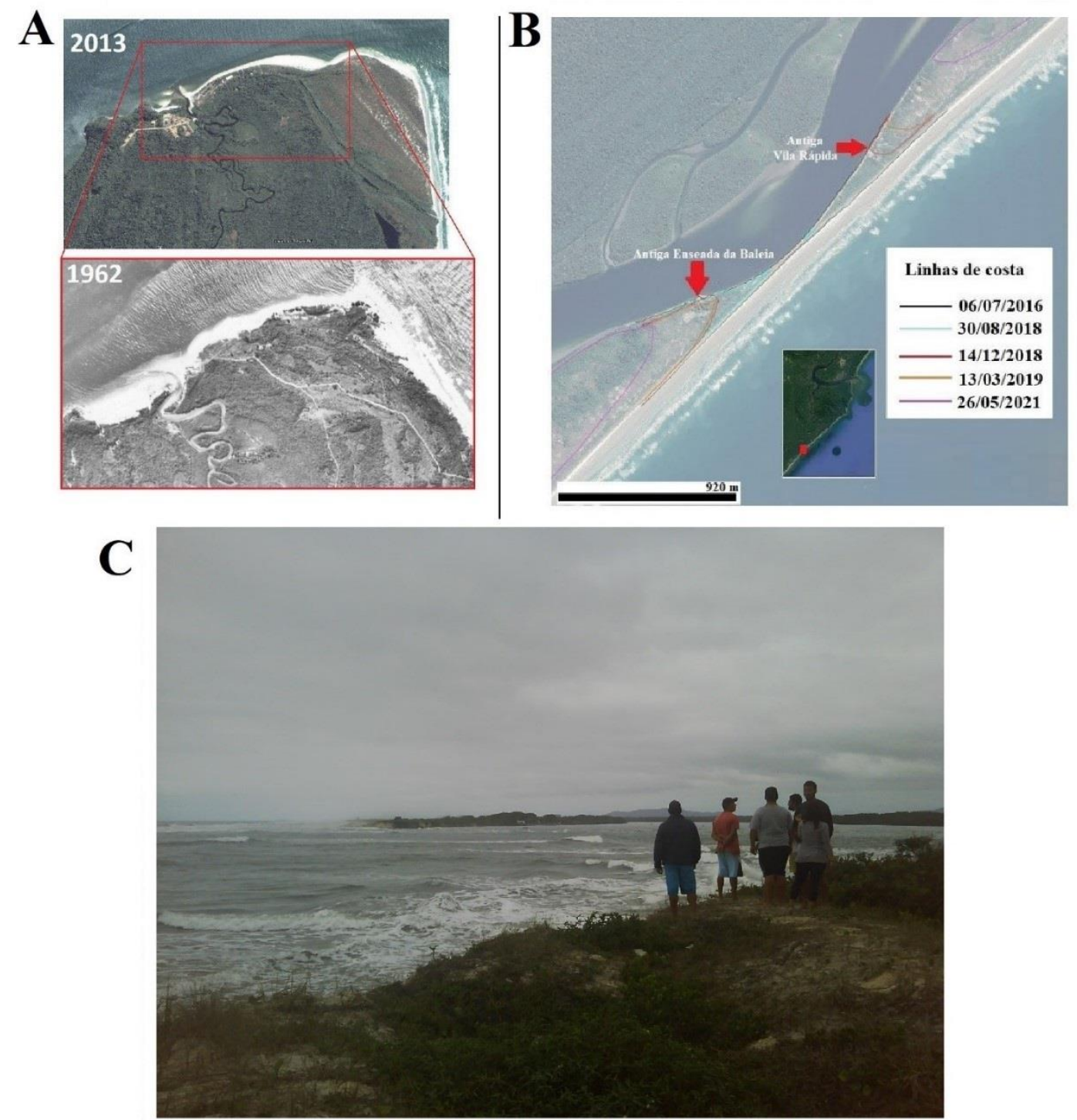

Figura 4 - Modificações do mar nas imediações de distintas comunidades da llha: A - mudanças no posicionamento do mar próximos a comunidade da llha voltada para Mar de Dentro (Pereirinha-Itacuruça), ilustrada por comparação entre fotografia aérea de 1962 e imagem da composição World View de 2015, onde se vê que porção significativa das estruturas da comunidade instalam-se em terrenos que pouco mais

de cinco décadas antes eram mar, B: mapa ilustrando modificações da linha de costa próximas a comunidades voltadas simultaneamente para Mar Aberto e Mar de Dentro (antigas Enseada da Baleia e Vila

Rápida) após o rompimento do Cordão do Ararapira, onde se situam, C: membros da comunidade da Enseada da Baleia e seus convidados observam abertura formada no Cordão do Ararapira, uma semana após o rompimento da llha do Cardoso em duas ilhas menores.

Fonte: adaptado de Cheliz (2015), Cheliz et al (2019), e foto de acervo pessoal do primeiro autor.

As Planícies vinculam-se a segmentos de menores altitudes (entre 0 e 20 metros acima do nível do mar), declives mais brandos (inclinações são majoritariamente inferiores a 5 graus) e associam-se a depósitos sedimentares e solos arenosos e argilosos. Mostram-se segmentadas em três subconjuntos: Planícies Costeiras, Planícies Litorâneas e Planícies Alagáveis. As Planícies Costeiras mostram-se mais expostas à ação direta dos fortes ventos vindos do mar e laguna circundante, e dos pontuais extravasamentos das águas ligados às tempestades mais intensas. As Planícies 
Litorâneas são usualmente ligeiramente mais elevadas que as Planícies Costeiras e usualmente mais distantes da linha de costa do Mar de Fora, estando assim resguardadas da ação atual mais intensa das águas circundantes e dos ventos vindos dela. As Planícies Alagáveis mostram-se rentes ao nível do mar, e associam-se a manguezais, sendo diariamente tomadas por extravasamentos das águas circundantes (figura 3).

\subsection{A incorporação das terras e das águas nos territórios caiçaras antes da conversão da llha em unidade de conservação}

Os atributos dos principais conjuntos de quadros naturais (figuras 5 e 6 ) da llha apresentam múltiplos elementos que podem ser tomados como componentes dos "recursos naturais" (ZEDEÑO, 2008) na construção dos territórios caiçaras ao longo do tempo. A presença das amplas Serranias (figura 5), de suas múltiplas nascentes e rios, e dos mais férteis solos derivados de seu embasamento rochoso (face maior diversificação e disponibilidade de elementos químicos essenciais para nutrição vegetal dados pela decomposição das fundações rochosas serranas - Cheliz, 2015), em contraponto aos solos de mais difícil cultivo das planícies, facultavam aos grupos caiçaras estabelecerem ali acesso favorecido a agricultura e a pesca. Particularmente, os sopés (Baixas Vertentes) e segmentos dos morros dispersos das Serranias apresentam também outros atributos particularmente valorizados pelos modos de vida caiçaras locais (CARVALHO e SCHMITT, 2012): 1 - declividade relativamente reduzida dos terrenos (quando comparado a segmentos mais elevados das serranias), que facilitam a instalação de casas; 2caráter navegável dos rios de fundo de vale, ligado aos declives reduzidos de suas calhas, o que possibilitava escoar excedentes da produção familiar para escambo ou venda junto a outros grupos sitiantes, ou com navios comerciantes vindos de Santos. De maneira similar, ressalta-se a própria abundância de peixes atribuídas aos rios serranos em seus segmentos com calhas de menores declives, incluindo espécies não presentes nos segmentos de água salgada ou salobra nos entornos da ilha, conforme relatado por entrevistas semi-estruturadas. 

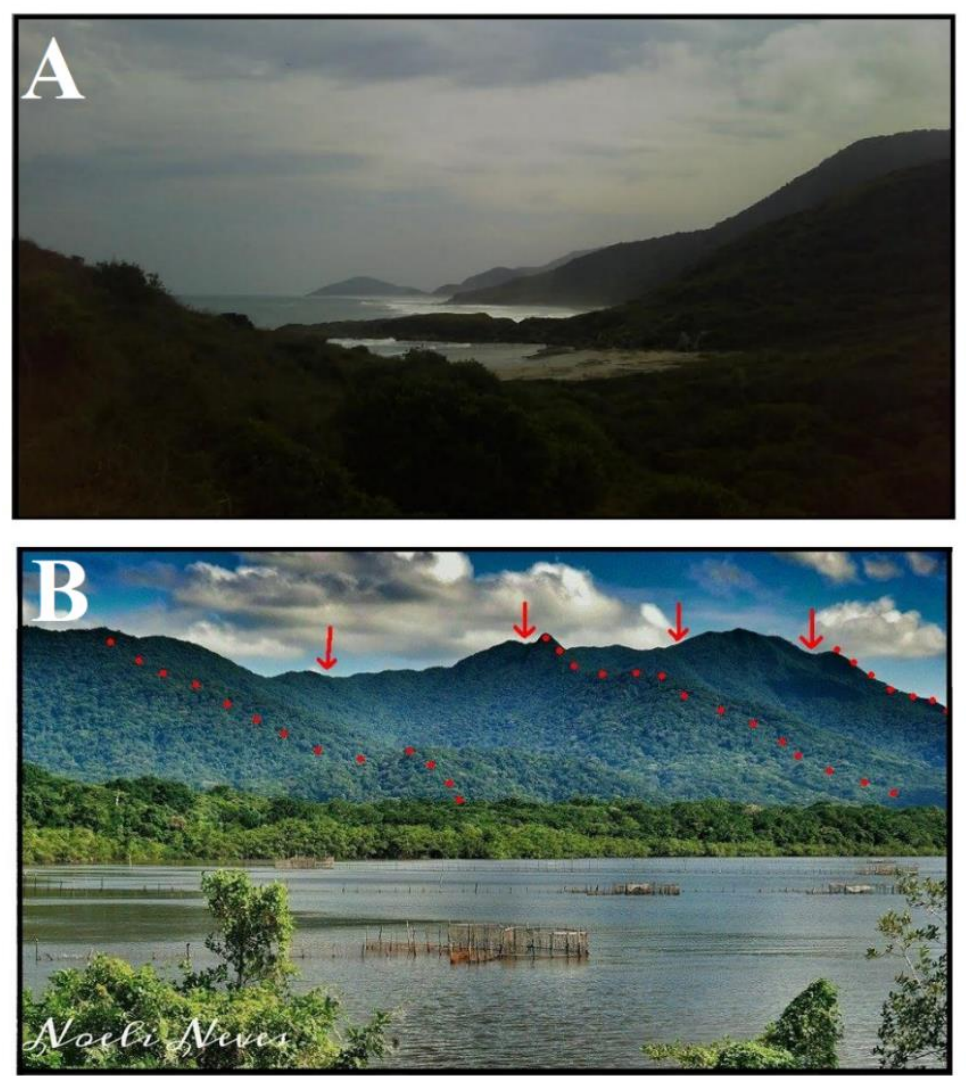

Figura 5 -composição ilustrando Serranias da llha do Cardoso, unidade da paisagem usada com maior intensidade pelas comunidades caiçaras locais antes da conversão da área em unidade de conservação. A: fotografia destacando esporões que se desmembram do corpo principal das Serranias e seccionam Planícies, formando praias embaiadas tomadas como local de instalação das comunidades voltadas para o Mar Aberto tais como Cambriú e Foles, B: Serranias voltadas para o Mar de Dentro, próximas da comunidade do Pereirinha-Itacuruçá. Pontilhados destacam esporões que se desmembram do corpo principal das Serranias e se prolongam rumo as águas do "Mar de Dentro", e setas interflúvios mais elevados. Observar armadilhas para peixes ("cerco-fixos") espalhadas ao longo das águas lagunares.

Fonte: adaptado de Cheliz (2015) e fotografia de Noeli Neves (2013)

Grupos caiçaras instalavam as casas de madeira e pedras de seus núcleos familiares próximos aos sopés das Serras e usavam de clarões na vegetação para prática de agricultura nas encostas suavizadas das Baixas Vertentes desde, ao menos, o século XIX (ALMEIDA, 2005; CARVALHO e SCHMITT, 2012; CHELIZ, 2015). As planícies ocuparam, no longo período anterior ao estabelecimento de restrições normativas mais rígidas de uso da terra local, um lugar então tido como menos visado para atividades dos núcleos familiares sitiantes, como elenca Almeida (2005). Tal distinção teve, de acordo com entrevistas realizadas, contribuições das percepções pelos caiçaras dos solos das áreas designadas como Planícies por Cheliz (2015) serem menos favoráveis e férteis para o cultivo agrícola do que os solos das Serranias, de maneira semelhante ao caracterizado pelo autor supracitado em sua análise do meio físico local. Esta coincidência entre a leitura dos elementos aqui considerados como "quadros naturais" por estudos acadêmicos e pelos caiçaras tradicionais locais é semelhante ao documentado 
por Ramires et al. (2020) em outras comunidades caiçaras do litoral sul de São Paulo, ao comparar conhecimentos advindos dos grupos de pescadores artesanais caiçaras e os de estudos de ecólogos.
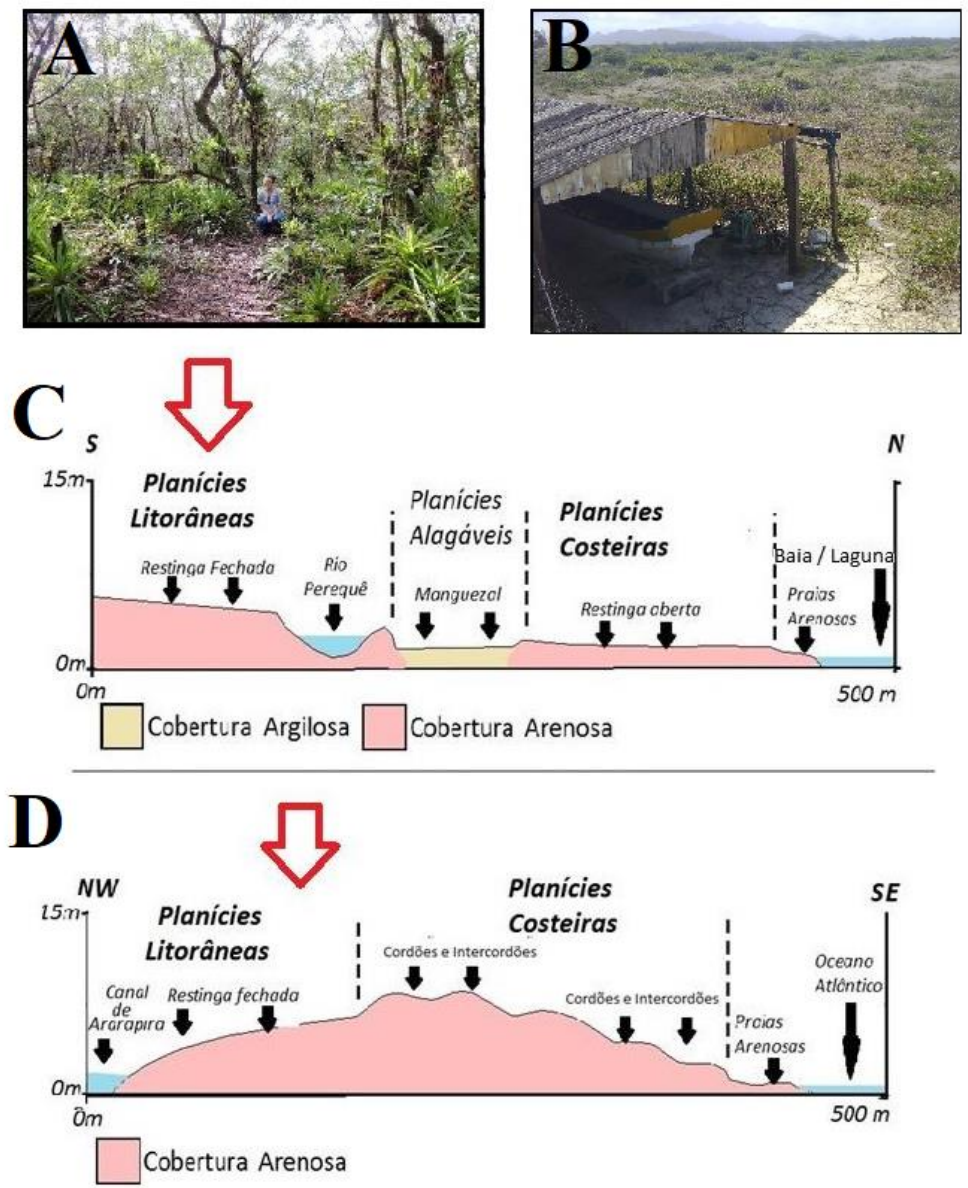

Figura 6 - composição ilustrando Planícies Diversificadas: A: - Planícies Litorâneas, B - Planícies Costeiras, C- perfil esquemático apontando subdivisões das Planícies no segmento voltado para laguna ("Mar de Dentro") com seta vermelho indicado local de instalação da comunidade do Pereirinha-Itacuruça, D- perfil das Planícies voltadas simultaneamente para águas do Canal do Ararapira (também designado como "Mar de Dentro") e ao Oceano Atlântico ("Mar de Fora"), com setas vermelhas indicando áreas (transição entre

Planícies Litorâneas e Planícies Costeiras) favorecidos para fixação das comunidades do Marujá, Vila Rápida, Enseada da Baleia e Pontal do Leste.

Fonte: adaptado de Cheliz (2015).

Relatos advindos dos testemunhos de moradores locais apontam que eles reservavam os segmentos da llha caracterizados como Médias e Altas Vertentes das Serranias por Cheliz (2015) para incursões esporádicas, em busca de itens vegetais e de fauna tido como mais frequentes nas altitudes mais elevadas. Profusão e diversidade das coberturas vegetais possibilitavam um amplo leque de apoios para a vida diária das comunidades - incluindo plantas tomadas como medicinais. Forneciam, ainda, respaldo para obras de trabalho coletivo amplo, como a esculturação de embarcações a partir dos troncos de árvores mais espessas trazidos das escarpas da llha para próximo dos rios e 
das planícies através de grandes mutirões de auxílio mútuo entre as comunidades caiçaras, conforme caracterizado por entrevistas semi-estruturadas realizadas.

Igualmente, as entrevistas ressaltam a abundância de nascentes (e.g - pequenas fraturas em meio às rochas) nas vertentes deste segmento das Serranias, que jorram de acordo com os relatos "águas de beber", classificação que não se estendia a água dos rios das planícies, tidas estas como "águas para pescar" e "águas para navegar", mas impróprias para saciar a sede. De fato, mesmo nos dias atuais, comunidades situadas adjacentes a rios das planícies (e.g - Pereirinha-Itacuruça) não usam de suas águas para beber, preferindo manter estruturas de dutos simples que trazem águas das cachoeiras serranas (distantes mais de $1 \mathrm{~km}$ ) da llha do Cardoso para as planícies. No caso de parte das comunidades do Cordão do Ararapira mais distantes do corpo principal das Serranias do Cardoso (e.g - Pontal e Enseada da Baleia), dutos similares foram feitos para trazer água de fora da llha, a partir de captações em porções serranas de cachoeiras de ilhas adjacentes ou do continente próximo, exigindo, assim, uma quantidade maior de trabalho para sua criação e manutenção, uma vez que neste caso é necessário fazer a travessia do Canal do Ararapira, tal como também descrito por Nabhan (2021). Ainda de acordo com as entrevistas, as pronunciadas declividades das áreas mais elevadas das Serranias, bem como maior instabilidade e propensão a movimentos de massa (CHELIZ, 2015; CHELIZ e OLIVEIRA, 2021) por ocasião de grandes tempestades ("trovoadas", como designadas pelos caiçaras nas entrevistas realizadas), fez com que fossem relegadas como opção preferencial de instalação duradoura, a despeito dos supracitados conjuntos de características tidos como valorizados.

Afora os núcleos familiares sitiantes, a instalação na llha de unidades produtivas dispersas (incluindo um estaleiro) de controle externo ao das famílias caiçaras locais, deslocou parte da população que trabalhava com a produção agrícola. A partir de 1910, barcos vindos da cidade de Santos também passaram a circular na fachada litorânea da Ilha, e se propõe a compra de pescado de Cananéia, o que teria contribuído para a pesca ser vista com um novo viés. Relatos advindos de entrevistas realizadas com moradores mais antigos (>70 anos) apontam que o navio circulava ao longo da maior parte da orla costeira da llha, abordando as múltiplas comunidades e núcleos sitiantes individualmente para adquirir pescados. Dentro do contexto trabalhado, a economia do caiçara local era tanto distinta da do indígena quanto da economia industrial. Ela buscava atender necessidades domésticas, e simultaneamente precisava de materiais que os próprios caiçaras não eram capazes de produzir - como ferramentas de aço, sal, e pólvora, tal 
como aponta Adams (2000). Até meados do século XX, em períodos tidos como de prosperidade, o caiçara deixava em segundo plano às suas atividades tradicionais, podendo adensar os núcleos urbanos. Voltava a colocar as atividades tradicionais em seus territórios com uma maior centralidade nos períodos de estagnação, buscando garantir a sua sobrevivência (ADAMS, 2000; MOURÃO, 2003), tal como no grande colapso econômico regional que se deu do Vale do Ribeira ligado ao assoreamento do porto de Iguape no fim do século XIX (BRAGA, 1998).

A llha chegou, assim, ao fecho da primeira metade do século XX com polaridade entre pontuais unidades produtivas remanescentes - de fábrica de telha a serralheria - e os previamente citados predominantes territórios dos núcleos sitiantes familiares voltados para pesca e agricultura diversificada de subsistência e colheita, escambo ou venda de eventuais excedentes. Até meados da primeira metade do século XX setores expressivos da população do próprio município de Cananéia fixavam-se na Ilha do Cardoso. Para a adjacente Ilha de Cananéia coube longamente no período histórico pós-cabralino o papel de abrigo e mesmo refúgio das incursões marítimas de corsários e piratas, e/ou de centro religioso.

\subsection{Relação entre as comunidades com as terras e as águas após a normatização da ilha como uma unidade de conservação ambiental}

A configuração judicial da llha do Cardoso como Unidade de Conservação e Parque Estadual (Decreto $n^{\circ} 40.319$, de 3 de julho de 1962) na segunda metade do século XX contribuiu para modificações significativas na mediação entre a ação humana e quadros naturais na construção dos territórios locais (GADELHA, 2008; CARVALHO e SCHMITT, 2012; CHELIZ, 2015; YAMAOKA, 2019). Com as restrições da nova normatização territorial para a prática de agricultura e para a manutenção das unidades produtivas residuais, iniciou-se massivo processo de êxodo populacional da llha do Cardoso rumo ao centro urbano da vizinha Ilha de Cananéia. Estima-se que ao menos 20 núcleos de povoação foram esvaziados (GADELHA, 2008; NUPAUB, 2016) - figura 7. As comunidades que praticavam de maneira mais intensa a agricultura antes da normatização do parque (e.g - tais como Marujá e Pereirinha, situadas adjacentes a morros e outras áreas onde se faziam roças) se viram mais impactadas, enquanto as que já eram mais ligadas à pesca afirmam terem percebido mudanças menores no seu dia-adia - como apontado pelas entrevistas realizadas na comunidade da Enseada da Baleia por Yamaoka (2019). Permaneceram, assim, na llha os grupos melhor adaptados à 
prática da pesca ou que conseguiram se adequar a ela (MARINHO, 2014), com atividades caiçaras em parte deslocando-se dos sopés das escarpas serranas e morros dispersos (onde antes se praticava prioritariamente a agricultura) para as Planícies da orla litorânea, de acordo com relatos das entrevistas. Mesmo grupos instalados nos segmentos litorâneos passam a ter dificuldades diversas para permanência, em parte apontadas como ligadas a restrições de ocupação por se situarem numa área de conservação. Passando a haver modificação em alguns dos componentes que Zedeño (2008) elenca como parte da construção da territorialidade. Na medida, sobretudo, em que o controle sobre as áreas dos territórios dos múltiplos núcleos caiçaras da llha passam a sofrer influência também da nova normatização legal de uso das terras alocada pelo Estado.

Concomitantemente, de acordo com relatos de entrevistas e Gadelha (2008), antigos clarões destinados às roças em meio às Serranias e mesmo Planícies foram sendo substituídos gradativamente por associações vegetais secundárias de restinga. Matas retomam extensões perdidas das roças, sítios e vilas caiçaras esvaziadas, enquanto os grupos caiçaras que se dispunham a permanecer buscam caminhos e estratégias para se adequarem ao novo cenário.

Pontualmente singularizam-se dispersas em meio as matas de restinga restos de muros e fundações de rocha. Pequenas e abandonadas casas de madeira surgem quase imperceptíveis, com janelas vazias e portas entregues as areias do tempo. Em muitos segmentos as antigas construções encontram-se parcialmente recobertas pela vegetação, que clamam a si mesmo estes pequenos nichos que desafiam sua dominância. $\mathrm{O}$ que para muitos são apenas escombros na véspera de serem tomadas pelas matas, para outros - como registrado nas entrevistas dos antigos moradores das comunidades que se esvaziaram, seja as do presente trabalho seja as de contribuições anteriores, como as de Gadelha (2008) - são símbolos que fazem vir à tona paragens antigas. Emergem vozes em meio às árvores. Em relances, rostos dos que há muito não caminham pela Ilha mostram-se em meio aos lampejos das águas dos córregos. Através da memória dos mais velhos, ou pelas histórias e canções dos fandangos herdados pelos mais novos, o tempo desnuda-se. Vastas extensões das matas de restingas em volta das antigas ruínas passam a dar lugar a clareiras com laranjais em esplendor, roças antigas e moradas passadas erguidas por fortes braços. Opulência das capoeiras gradam para o perfume de campos floridos e figueiras espaçadas em meio aos quintais das casas dispersas, dando alcance à visão ao imenso mar que parece tomar o tamanho do mundo (CHELIZ, 2015). 


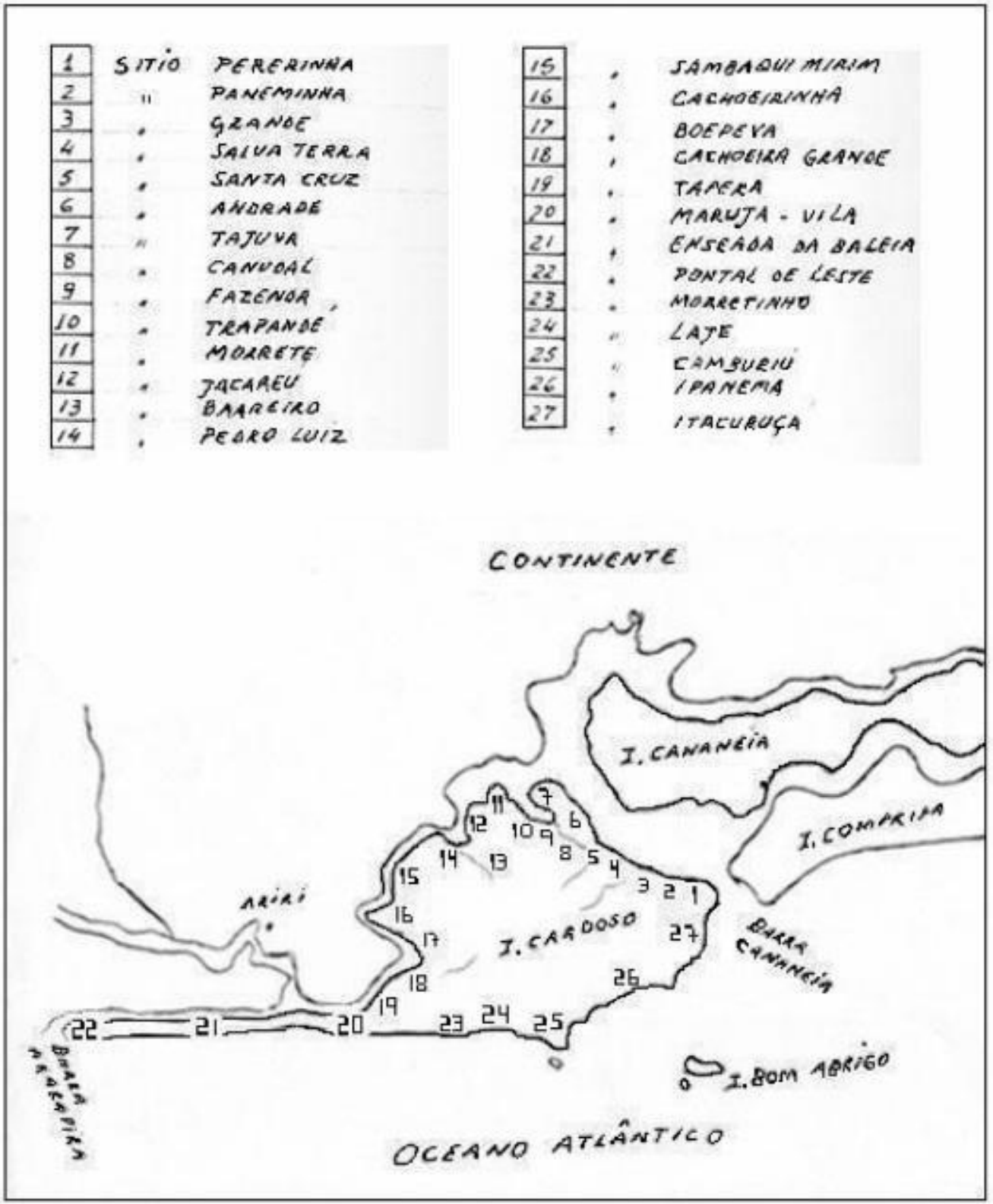

Figura 7 - esboço com localização de parte das comunidades da llha anteriores a normatização do parque como unidade de conservação.

Fonte: adaptado de Gadelha (2008).

O silêncio das matas é cortado pelo som fluído das conversas e canções que embalaram os laços de comadres e compadres. Pelo eco do destino incerto das pequenas rabecas que um dia ali ressoaram. Do toque das mãos que acariciavam, e pelo estalar de distantes fogueiras noturnas. Lembranças de cabelos esvoaçantes ao vento daqueles que se lançavam ao mar. Do arroz nascente dos que fincavam-se a terra firme. Fragmentos que se esvaíram como o vento nas praias. Dividindo o mesmo domínio onde reinam o silêncio e a contemplação dos anos de mudanças do mar que ora criam, ora destroem parte das terras locais. Memórias de laços rompidos com a terra e águas na qual cresceram, e cujos vínculos profundos a elas mantinham-nos unidos mesmo depois da partida, como a uma mãe. Vivências, tristezas e alegrias de vidas inteiras. Chamados 
daqueles que já partiram. Saudades profundas. Caracterizando, assim, em parte, a passagem de algumas das áreas da llha como de antigos territórios para paisagens culturais, tidos como lugares ricos em significados vindos das experiências de um tempo de ocupação pretérita por um certo grupo em dada área, conforme definição de Zedeño (2008). Elencando, ainda, modificações nos elementos que definem a territorialidade de acordo com a mesma autora - permanecem as emoções, memórias e sentimentos agregadas a uma área específica, mas enfraquece-se o controle e o acesso a ela.

As lembranças e ruínas nas margens dos rios, lagunas e sopés serranos não passam a serem, porém, os únicos elementos que rompem a onipresença das densas matas e capoeiras das Planícies da llha. Espaçados entre as quase que insondáveis matas de restingas mostram-se pequenos clarões onde as pessoas ali permanecem e mantém-se em seus territórios a despeito das dificuldades, num total de cerca de 500 habitantes que chegam aos dias atuais, distribuídos em sete comunidades caiçaras (figuras 3 e 8 ). Sua persistência, porém, envolveu o enfrentamento de obstáculos e dificuldades diárias (como relatado pelas entrevistas semi-estruturadas realizadas), entre eles a adequação à nova normatização do território e à própria dinâmica físico-natural da área costeira da llha. Grupos de caiçaras que permanecem veem-se inseridos numa zona de encontro entre céu, terras e águas que por vezes podem se combinar de maneira intensa e destrutiva (CHELIZ, 2015). Neste contexto, pode-se inicialmente segmenta-las em três grupos quanto a sua mediação com os quadros naturais da llha: 1- as comunidades que instalam-se em terras voltadas para o segmento lagunar - "Mar de Dentro" , 2- as que encontram-se em terras voltadas simultaneamente para as águas lagunares e para as águas oceânicas, 3 - as que instalam-se em terras voltadas para as águas oceânicas - "Mar de fora" (figura 3).

No segmento meridional da Ilha, a comunidade do Pereirinha-Itacuruçá constitui a comunidade voltada para o segmento lagunar ou "Mar de Dentro". Ergueu-se no limite entre restingas abertas e fechadas defronte a Baia de Trapandé, adjacentes a um morro residual ("Morro do Pereirinha") batido pelas águas marinhas, e perto da foz de um grande rio local - Rio Perequê. O rio, inclusive, separava o que originalmente eram duas comunidades diferentes - a de Itacuruçá, a leste do rio, e a do Pereirinha, a oeste. A comunidade Pereirinha-Itacuruçá originou-se, assim, a partir do agrupamento de várias famílias - sobretudo os Rangel, Neves e Cordeiros - que em parte se tornaram dispersas pelas Planícies do Nordeste da llha, conforme êxodo e migrações partindo da llha se acentuavam (conforme entrevistas semi-estruturadas realizadas com moradores locais). 
Parte de seus núcleos familiares se instalarem ali antes da criação do parque, pois tiveram suas localidades anteriores (no sopé da Serra, e, num segundo momento, na foz do rio Perequê, e no sopé do Morro do Pereirinha) ameaçadas pelas forças das enchentes ou movimentos de massa alguns anos antes mesmo da conversão da ilha em unidade de conservação, conforme relatos de entrevistas realizadas.

As comunidades de Pontal do Leste, Enseada da Baleia, Vila Rápida e Marujá envolvem aquelas que se encontram voltadas simultaneamente para as águas lagunares e para águas do mar aberto. Núcleo do Pontal do Leste ergueu-se no extremo sudoeste da llha, próxima a Barra do Ararapira. Formou-se a partir das alianças de casamento entre nascidos na llha e outros de localidades múltiplas do continente próximo ou de ilhas adjacentes, como Superagui - sendo os sobrenomes Pires, Cunha e Ramos como mais comuns que chegam aos dias atuais. Longamente dividiram-se entre a pesca no Pontal e a agricultura no continente próximo, com famílias tendo comumente no passado duas moradias. A comunidade da Enseada, por sua vez, levantou-se em clarões em meio ao Cordão de Ararapira, de frente a laguna e de costas para o mar. Seu alicerce envolve os descendentes do casamento de filhos adotivos de casal isolado que ali habitava - família Malaquias Cardoso, conforme informações fornecidas pelas entrevistas e pelos levantamentos do padre João Trinta compilados e aprofundados por Carvalho e Schmitt (2012).

A Vila Rápida, em seu turno, se instala em meio às dunas do mesmo Cordão. Longamente foi considerada como extensão da própria Enseada, herdando seu nome atual do fato de turistas terem erguido ali casas de veraneio com grande velocidade, visando escapar das restrições impostas pela Unidade de Conservação - conforme entrevistas semi-estruturadas realizadas e Carvalho e Schmitt (2012). Ali, são mais comuns os sobrenomes Mendonça e Ramos, com a comunidade sendo habitada desde, ao menos, a primeira metade do século XX. A comunidade do Marujá, por sua vez, fixouse também no Cordão, mas mais próxima das bases das Serranias. O Núcleo herda o nome de antigo barco que ao cruzar o Canal de Ararapira teve seu trajeto interrompido por ser associado a geração de grandes ondas que atrapalhavam embarcações menores, tendo que ali aportar. A comunidade que nas proximidades do antigo barco se instalou teria tomado emprestado o nome da embarcação citada, em substituição a antiga toponímia de "Praia do Meio" usada anteriormente para designar o segmento em questão (CARVALHO e SCHMITT, 2012; CHELIZ, 2015). 
A instalação voltada exclusivamente para o mar aberto envolve as comunidades de Foles e Cambriú - onde são mais comuns os sobrenomes Neves, Cubas e Mendes. Ambas comunidades, porém, contando com respaldos específicos. A comunidade de Foles ainda que esteja a poucas dezenas de metros da linha de arrebentação de ondas tomou a praia embaiada homônima para se fixar. Encontram-se, assim, resguardados da ação mais agressiva do mar por dois salientes esporões rochosos.
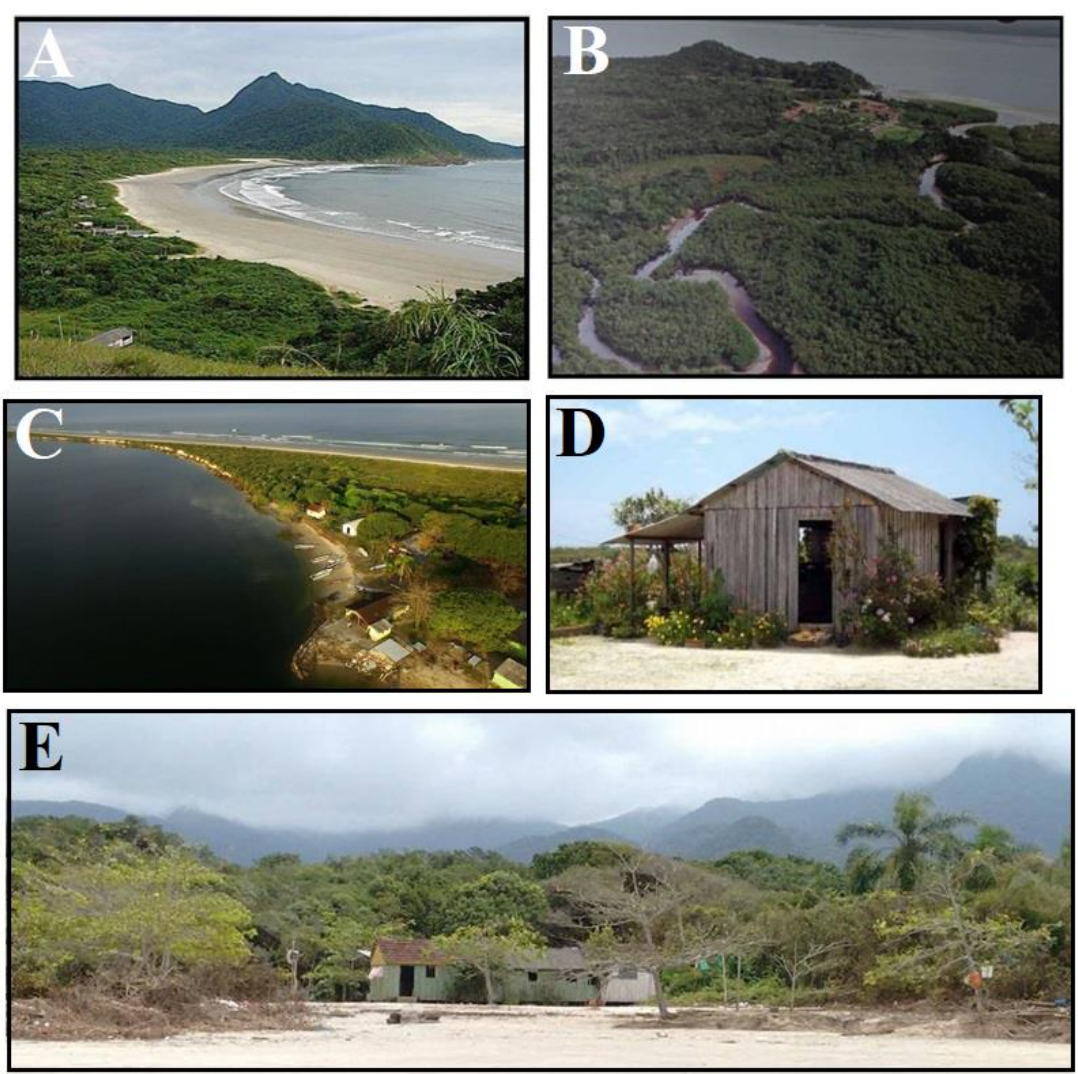

Figura 8 - composição com ilustrações das comunidades remanescentes: A - fachada de comunidade voltada exclusivamente para o mar aberto (Cambriú); B: fachada de comunidade voltada para o Mar de Dentro (Pereirinha-Itacuruçá), onde se vê também o traçado meandrante do rio Perequê; C: fachada de comunidade voltada simultaneamente para Mar de Dentro e Mar de Fora (antiga Enseada da Baleia), D: detalhe de casa de comunidade (antiga Vila Rápida) voltada simultaneamente para Mar de Fora e Mar de

Dentro; E: casas de comunidade voltada para mar aberto (Cambriú).

Fonte: adaptado de Cheliz (2015), Silva (2014) e Diana Garça (2016). Imagem "B" de autores desconhecidos, e disponibilizada do arquivo do Parque Estadual da Ilha do Cardoso, e imagem " $\mathrm{C}$ " do arquivo comunitário da Enseada da Baleia.

Já o núcleo do Cambriú ergueu suas pequenas casas de madeira em meio a clareiras na restinga fechada adjacente aos trechos finais de praias arenosas da costa sudeste da llha. A comunidade instala-se numa pequena faixa de Planícies situadas entre Serranias a oeste, um esporão rochoso a sul e os abruptos paredões sob arrebentação do mar do Costão do Cambriú que domina o horizonte a norte (figura 2a e 8a). A discreta enseada margeia ainda a foz do rio Cambriú, que em seus segmentos finais contorna os paredões abruptos da Serra e marca os limites das praias brancas arenosas locais. Águas 
doces e salgadas se encontram sob a guarda dos imensos paredões rochosos e visão distal dos mais serrilhados picos rochosos da llha. O som contínuo dos intensos choques das ondas ante os costões se mescla à suavidade pontual da anulação da arrebentação imediatamente defronte às várias pequenas casas de madeira da comunidade, em meio à profusão de cores das flores e árvores das restingas. Sensações múltiplas de difícil apreensão se mesclam, num dos talvez mais singulares quadros de interações entre caiçaras e quadros naturais de toda a Ilha.

Nos vários núcleos dispersos ao longo das planícies da llha e em meio a estreitos clarões arenosos das matas de restinga, as comunidades mantiveram suas moradas, com salões comunais, capelas e pequenas casas. Discretas trilhas em meio a cordões arenosos e matas de restingas abriram-se, ligando a entrada de seus lares as de seus vizinhos e aos portais para um aparente infinito oceano, conforme percepções relatadas de entrevistas. Suas crianças ali dão os primeiros passos, e a vida começa a seguir seus caminhos. Nas primeiras brincadeiras, se inicia o apreender dos ritmos dos mares, peixes e ventos. Dos trajetos das estrelas e céus. O árduo, mas compartilhado trabalho na pesca e a delicadeza sutil na confecção de suas comidas, instrumentos e ferramentas. A alegria sincera e ingênua das noites de festejos anuais dos padroeiros de cada uma das comunidades. Descobertas e o nascimento dos laços, como mais uma semente brotando nos solos das matas de restingas. O amparo dos seus e a segurança da terra firme dividida com o permanente murmúrio marginal da arrebentação dos mares, como um chamado para um incerto e desconhecido futuro (CHELIZ, 2015).

A aparente fragilidade e leveza das edificações e a distribuição horizontal das referidas comunidades em meio a compartimentação de relevo da llha podem ser tomadas como uma estratégia localizacional, que leva em consideração não somente os atributos dos quadros ambientais das águas dos entornos, mas também dos distintos atributos das terras emersas. Uma vez que ao sobrepormos a localização das comunidades com os levantamentos geomorfológicos da llha (figuras 3, 6 e 8), verificamos que existe uma coincidência da localização das atuais comunidades com o limite entre duas das subunidades de relevo (Planícies Litorâneas e Planícies Costeiras) que caracterizam as terras baixas locais. A opção de erguerem suas comunidades nas Planícies Litorâneas, mas próximas das Planícies Costeiras, permitem com que consigam instalar as suas famílias e resguardar suas moradias e locais de trabalho em terra firme das ingressões periódicas mais intensas das águas. Contam, assim, com o anteparo das restingas abertas, cordões e dunas das Planícies Costeiras para protegê-los dos efeitos 
nocivos dos intensos ventos e inundações das águas lagunares e marinhas dos entornos, por ocasião das passagens de frente frias e tempestades mais intensas. Simultaneamente, encontram-se próximos o suficiente das praias (caminhadas de não mais do que cinco minutos) para terem acesso aos distintos conjuntos de águas circundantes. Adicionalmente, a possibilidade de acesso rápido ao transporte pela laguna e pelo mar para outros núcleos e comunidades é outra vantagem oferecida pela instalação próxima ao limite entre as Planícies Litorâneas e Costeiras, haja vista a dificuldade imposta pelas Serranias que dominam o centro da llha para realizar estes trajetos por terra, conforme relatos das entrevistas realizadas. Igualmente, nota-se que a maioria das comunidades situa-se próximas $(<1 \mathrm{~km})$ de Planícies Alagáveis, cujos manguezais associados são vinculados a múltiplos animais e plantas incorporados no diaa-dia das comunidades, sobretudo antes da conversão da llha em unidade de conservação.

\subsection{Flutuações dos usos das terras e águas e o papel da pesca nos diferentes conjuntos de territórios tradicionais ao longo do tempo}

\subsubsection{As comunidades e as mudanças e permanências do uso da terra, das águas e da pesca}

Cada um dos três conjuntos de comunidades pesqueiras (aquelas com acesso direto a águas lagunares, as com acesso direto simultâneo as águas lagunares e oceânicas, e as com acesso direto a águas oceânicas) experimentaram diferentes variações de seus modos de vida e de uso da terra e das águas após a conversão da llha do Cardoso em unidade de conservação, conforme entrevistas realizadas. Tais mudanças, porém, se dão incluindo também diferentes permanências e modificações nos modos de pesca - a principal prática que articula a vida em terra e em mar dos moradores locais - em si, quanto a oscilações da centralidade da pesca para a subsistência dos membros das comunidades. De maneira similar, de acordo com entrevistas semiestruturadas, os caiçaras locais associam potenciais e riscos diferenciados das práticas pesqueiras a cada um desses conjuntos de águas aos quais as terras das comunidades tem acesso direto. Mostrando-se nisso semelhantes às toponímias de pescadores artesanais voltadas para segmentação de peixes previamente elencadas por Mourão e Nivaldo (2018) no litoral da Paraíba, no nordeste brasileiro, e aos conhecimentos tradicionais de pescadores documentados por Ramires et al. (2007). Envolvendo, ainda, 
distintos tipos de mediações e trabalhos a partir dos produtos das pesca (figuras 9 e 10), conforme detalhados nos tópicos seguintes.

\subsubsection{Atividades pesqueiras e interfaces terra-mar voltadas para o Mar de Dentro}

O "Mar de Dentro" é apontado nas entrevistas semi-estruturadas pelos pescadores de distintas comunidades como dotados de águas menos agitadas do que as do "Mar de Fora". A prática pesqueira no "Mar de Dentro" é vista, assim, como uma modalidade de pesca de menor risco aos seus praticantes. Entre as principais modalidades de pesca nas águas estuarinas pode-se elencar os cercos-fixos, rede de espera, caceio, cerco, currico, picaré e gerival, conforme entrevistas semi-estruturadas e coerente com $\mathrm{O}$ também caracterizado por NUPAUB (2016).

A primeira das citadas modalidades é descrita pelas entrevistas como a mais efetiva, e a que apresenta relação mais forte com as áreas que as comunidades tomam como seus territórios. Liga-se a uma conjunção de saberes do conhecimento tradicional herdado que convergem no uso de uma forma também tradicional de pesca (figura 9), a montagem de armadilhas de cerco-fixo. Tal modalidade de pesca tem uma importância que extrapola a das comunidades da llha, uma vez que nos meses de inverno chegam a responder por mais de $40 \%$ de toda a produção pesqueira do município de Cananéia como um todo, conforme os dados advindos da colônia de pesca municipal sistematizados por Cubas (2018). No passado as referidas armadilhas eram feitas com segmentos de madeiras (denominados de mourões) unidos entre si por cipós derivados do extrativismo da flora da própria ilha. Sua preparação envolvia trabalhos demorados, que exigiam mutirões de duração de várias semanas entre os membros de uma mesma comunidade. Uma parte do processo era constituída de várias semanas de trabalho em terra, e outra (mais breve, em geral se dando em poucos dias) na montagem dos mourões nas águas nos entornos, conforme detalhado no material suplementar 1.

Atualmente, devido às restrições ao extrativismo ligados a normatização da Ilha como unidade de conservação, a prática da pesca com armadilhas de cerco-fixo se mantém, mas com modificações, conforme entrevistas semi-estruturadas realizadas e acompanhamento direto de algumas destas práticas pesqueiras. No lugar de, como no passado, usar itens vegetais extraídos da flora da própria Ilha (prática que passou a ter restrições após conversão da llha em unidade de conservação), são usados varas de madeira compradas em armazéns das cidades próximas, e usados fios de arame também obtidos nas cidades para unir os festes de madeira entre si e formar os mourões. 
Permanecem, entretanto, o trabalho coletivo e o rodízio de mutirões entre membros das comunidades para preparar os mourões, transportá-los e montá-los em meio às águas circundantes. Incluindo uma sucessão de tarefas em que a posição dos núcleos de povoação em segmentos pouco distantes da linha de costa facilita a efetivação. Havendo, ainda, a necessidade dos cercos-fixos serem refeitos em média três vezes por ano por cada grupo de parceiros de pescaria, pois apresentam durabilidade média de 4 meses antes de serem desgastados pela ação das águas circundantes (CUBAS, 2018).

De maneira similar, permanecem também a preparação manual de apetrechos de pesca como as redes (confecionadas muitas vezes nas noites de inverno, e ao mesmo tempo que as famílias encontram-se reunidos sentados nas salas de suas casas a noite conversando sobre o dia) para coleta dos peixes capturados, mas agora não usando de produtos de extrativismo nos processos de confecção, e sim matérias-primas obtidas de fora da llha, usualmente nos armazéns das cidades próximas. Passam a empregar, ainda, barcos motorizados, em combinação com as tradicionais canoas a remo. Os barcos são usados para acesso mais rápido ao local de montagem do cerco, com as canoas sendo levadas "rebocadas", presas por cordas. Ao chegar ao local de montagem, porém, os parceiros de pescaria passam para a canoa não motorizada, tida como de movimentos mais precisos, que auxiliam a se posicionarem adequadamente para fixação dos mourões.

Esse conjunto de práticas seculares com adequações recentes têm enfrentado desafios para sua manutenção. Dentre eles, a percepção por parte dos pescadores da Ilha de diminuição da abundância de peixes no "Mar de Dentro" ao longo do tempo, atribuído por eles, em parte, a ampliação da circulação de barcos motorizados (sobretudo de turistas) e maior urbanização do litoral sul como um conjunto. Recentemente, soma-se aos citados desafios o anteriormente mencionado rompimento (figura 4) da porção sul das Planícies da llha do Cardoso (SOUZA, 2018; CHELIZ et al. 2019; SOUZA et al. 2019). A decorrente formação de uma nova barra do Canal do Ararapira seccionou a continuidade das Planícies da ilha, e expos uma porção significativa das águas lagunares - até então resguardadas em grande medida da ação direta das águas marítimas - a influência direta do Oceano Atlântico. Passaram a serem registrados, de acordo com entrevistas realizadas, modificações nos graus de salubridade das águas e oscilações bruscas dos padrões de circulações internas das águas. Tais mudanças súbitas são apontadas como muito significativas pelos grupos de pescadores locais. Sobretudo por suas estratégias de pesca no "Mar de Dentro" serem em parte alicerçados nos conhecimentos tradicionais 
herdados sobre os padrões das águas lagunares, e dos locais de abundâncias de peixes vistos como correlatos, que apontam como terem permanecido caracterizados por relativa constância ao longo de muitas gerações.
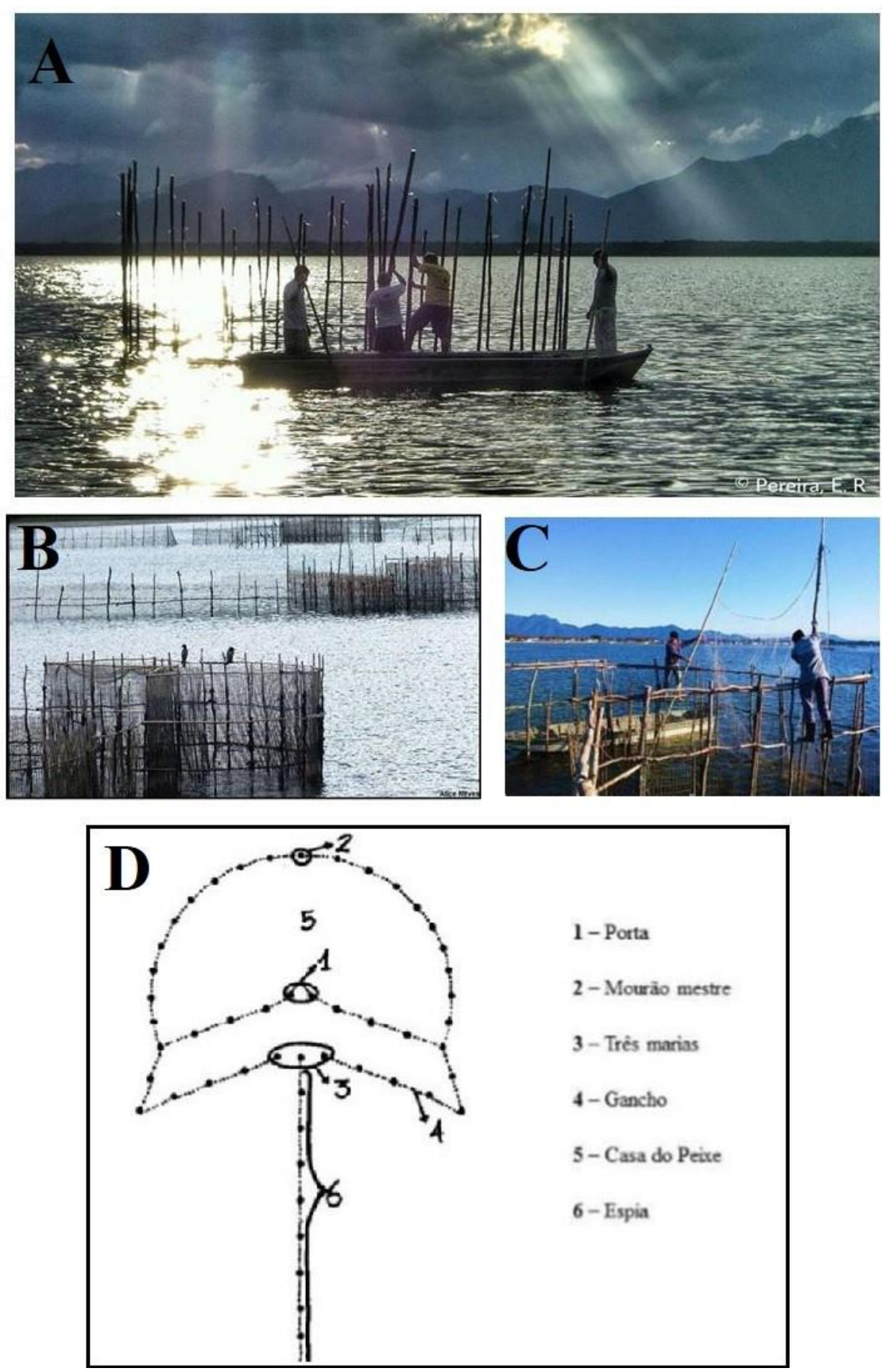

Figura 9 - ilustrações de montagem de cerco fixo, prática pesqueira usada no Mar de Dentro: A - fixação dos mourões por membros das comunidades do Pereirinha-Itacuruçá (foto de Eduardo Pereira), B fachada de cercos fixos já concluídos, próximos a comunidade do Pereirinha-Itacuruçá; $C$ - membros de comunidade local fazendo a coleta de peixes capturados na armadilha, D - esquema ilustrando planta de um cerco típico dos usados do "Mar de Dentro" a norte da llha do Cardoso.

Fonte: adaptado de Cubas (2018), fotos de Eduardo Pereira (2015), Alicia Neves (2015) e de Cheliz (2015).

O deslocamento de barcos ao longo do local passou também a ser modificado, usando de adequações de suas técnicas de orientação e navegação (e.g - COELHO, 2019), dado as mudanças na circulação das águas, e mesmo comunidades como a 
Enseada da Baleia e Vila Rápida tiveram que realocar-se devido a seus antigos locais de instalação na área de restinga terem sido engolidos pela nova barra (HAYAMA e CARDOSO, 2018; YAMAOKA, 2019).

Mesmo em segmentos mais afastados da nova barra, as águas mais calmas do "Mar de Dentro" por vezes também experimentam formação de ondas que podem ter mais de um metro, por ocasião da passagem de ventos e frentes frias mais fortes, que dificultam a navegação, conforme entrevistas e observação direta. A perícia caiçara e sua relação com as águas, nessas ocasiões, se manifesta por meio de estratégias especiais usadas para navegar em tais condições. Nos trabalhos de campo, notamos que ao fazer trajetos no "Mar de Dentro" entre a Ilha do Cardoso e a adjacente cidade de Cananéia nos dias de águas agitadas em pequenos barcos guiados por não-moradores da Ilha, eles conduziam a embarcação da mesma maneira que no tempo em que as águas locais se mostravam planas e calmas. O barco usualmente é conduzido por tais pessoas fazendo percursos em linha reta, formando ângulos obtusos em relação a propagação das ondas, e em velocidade constante e elevada, levando a contínuos e fortes impactos contra as ondas que a embarcação rompia sucessivamente, bem como a intensos solavancos. Viam, assim, essa adversidade das águas agitadas dada pelo meio natural local como algo a ser vencido com o máximo da potência fornecida pelos motores a combustão, de maneira a superar a energia das ondas.

Ao fazermos estes mesmos trajetos em similares embarcações guiadas por moradores caiçaras locais, por outro lado, percebíamos que eles mudavam sua forma de conduzir o barco para se adequar ao novo cenário das águas. A cada crista de onda que surgia, a avaliavam com um olhar, e suavemente mudavam o ângulo em que a embarcação se deslocava, para buscar aquele que mais se adequasse a forma da onda, de maneira a minimizar o impacto, que praticamente não sentíamos. No lugar de atravessar e romper com grande velocidade cada onda que tínhamos em nosso caminho, o barco passava, assim, a se deslocar suavemente sobre elas, adaptando-se e acompanhando a suas curvaturas naturais oscilantes, em sucessivos suaves sobes e desces. Para tal, os "piloteiros" caiçaras diminuíam e modulavam a velocidade da embarcação no momento em que o barco estava "cavalgando" suavemente a onda, a aceleravam um pouco discretamente após transpô-la, e diminuíam novamente face a aproximação da onda seguinte. Mostravam, assim, uma opção de adequação para o próprio deslocamento de seus barcos se tornar mais próximo desses novos e agitados ritmos e formas das águas, de maneira síncrona, tal como os melhores cavaleiros 
compreendem e se adequam às oscilações dos humores mesmo dos cavalos mais bravios.

\subsubsection{Atividades pesqueiras no "Mar de Fora"}

Referente ao "Mar de Fora", relatos de pescadores dos diferentes conjuntos de comunidades convergem no sentido de atribuírem a ele um maior potencial para pesca mais abundante. Sobretudo quando levam em conta a percepção de diminuição dos pescados no "Mar de Dentro", e as recentes alterações nos padrões das águas lagunares pela ruptura dos cordões arenosos da llha. Elencando-se como práticas pesqueiras predominantes o arrasto simples e de praia. Apontam que a chegada à llha de barcos com motores a combustão favoreceu a pesca embarcada no Mar de Fora, tida como de maior rentabilidade, tal como também realçado por Mourão (2003), e diferente do retratado previamente por Mendonça e Katsuragawa (2008) para os anos de 1995 e 1996, tempo em que a pesca artesanal na área foi caracterizada como pouco motorizada.

Simultaneamente, as entrevistas semi-estruturadas caracterizam a pesca no "Mar de Fora" como ligada a maiores riscos, face a maior agitação das águas, a maior profundidade e dificuldade de navegação, e as influências mais bruscas e diretas das tempestades associadas ao "Vento Sul”. Englobando, ainda, práticas pesqueiras de pesca artesanal a partir de pequenos barcos tripulados motorizados de madeira, equipados para possibilitar o pernoite ou passagens por ilhas rochosas menores no entorno do Cardoso, cujas imediação são ditas pelos moradores da ilha como caracterizadas pela abundância de pescados.

O apontado como elevado grau de preservação e baixa contaminação das águas locais do complexo lagunar de Cananéia-Iguapé, quando comparadas, por exemplo, com as áreas dos grandes complexos portuários da Baixada Santista ao norte e Paranaguá ao sul, é frequentemente mencionado pelos pescadores locais como tido como responsável pela elevada abundância de alguns importantes pescados no "Mar de Fora", como camarões. De maneira similar, esse tido como elevado grau de preservação - mesclado a raridade de áreas com águas preservadas no densamente urbanizado e industrializado Centro-Sul brasileiro - levam este trecho do mar local a ser visado por outros tipos de pesca que não o artesanal, controlados por agentes externos a llha e ao litoral sul de São Paulo, de forma semelhante ao documentado anteriormente por Chaves e Robert (2003) no litoral sul do Paraná. 
Em trabalhos de campo na llha, por várias vezes pudemos observar no início da manhã as pequenas embarcações dos pescadores artesanais se dirigindo ao mar aberto, e retornando poucas horas depois, quando o habitual seria que permaneçam por vezes vários dias seguidos na prática da pesca de camarão. Relatos de pescadores ao serem questionados sobre o tema, apontam que o retorno se dá quando constatam que houve uma diminuição brusca da abundância de camarões disponíveis no "Mar de Fora", voltando para suas moradas para tentar novamente a pesca após alguns dias. Atribuem tais diminuições bruscas a passagens de navios-pesqueiros industriais vindos de grandes centros urbano-industriais do sul e do norte, que praticariam durante a noite (visando dificultar a fiscalização) pesca industrial de arrasto de camarões (prática ilegal) no fundo do "Mar de Fora", levando numa única noite grande parte dos camarões passíveis de serem apreendidos por várias dezenas de pescadores artesanais ao longo de quase uma semana embarcados.

\subsubsection{Oscilações entre os diversos tipos de pesca, e o trabalho dos produtos do mar}

Ainda que a localização de cada conjunto de comunidades favoreça a pesca nos conjuntos das águas que se encontram situadas adjacentes, tal fato não restringe, necessariamente, as práticas de pesca de seus integrantes a um único conjunto de águas. Membros da comunidade voltada exclusivamente para o "Mar de Dentro" (Pereirinha-Itacuruçá), por exemplo, relatam tanto a prática da pesca nas águas lagunares (incluindo o uso de armadilhas de cerco), como no Mar de Fora (através da pesca de praia). Sobretudo no inverno se revezam para, usualmente no final do dia, deslocarem-se cerca de seis quilômetros rumo ao final da praia que se situa a comunidade (Praia de Itacuruçá), para terem acesso a costão rochoso alcançado pelas águas oceânicas do "Mar de Fora", visando a pesca de Tainha (apontada como mais abundante nesses segmentos de ligação do "Mar de Fora" com o "Mar de Dentro"). De forma semelhante, pescadores situados em comunidades sulinas voltadas para o mar aberto e laguna, relatam deslocarem-se no Outono para passarem alguns dias na comunidade nortista onde possuem laços de parentesco, para auxiliarem na preparação dos cercos-fixos, tidos como mais favoráveis em tal conjunto de águas. O estabelecimento de relações de "parceiros de pescaria" não se restringe, assim, necessariamente aos membros de uma mesma comunidade. Sobretudo, de acordo com relatos das entrevistas realizadas, pela existência de relações de casamentos entre membros de diferentes comunidades da llha 
(com tais casais frequentemente relatando terem se conhecido e iniciado seus laços nas festas dos padroeiros, que muitas vezes reúnem membros dos diferentes territórios tradicionais da Ilha).

As permanências e modificações das práticas da pesca em si ao longo do tempo se mesclam às transformações e constâncias das maneiras de trabalhar os produtos do mar. Exemplos desses processos podem ser observados numa das comunidades com acesso direto simultâneo às águas lagunares e oceânicas no Cordão do Ararapira ao sul da Ilha, a Enseada da Baleia. Ali, o interesse pelo pescado levou a instalação de uma fábrica de peixe seco que estava organizado para o beneficiamento da sardinha e do iriko. Antes da normatização do parque, a fábrica era - de acordo com relatos das entrevistas controlada por pessoa externa à comunidade e à llha, com o trabalho dos membros das comunidades sendo feito em troca de mercadorias. Esta fábrica faliu na década de 1940 e deu origem a uma nova forma de beneficiamento do pescado, através da salga e secagem ao sol, que dependia de alternativas para a ausência de sistemas de refrigeração no período (YAMAOKA, 2019). Num segundo momento, um grupo de mulheres da comunidade se organiza para fazer liderar a realização das supracitadas atividades, com características específicas semelhantes a de economia solidária (figura 10). Situando ali as mulheres em posições sociais diferenciadas das apontadas como tradicionais nas organizações dos núcleos caiçaras por Adams (2000).

A habilidade necessária para tal trabalho e secagem sistemática dos pescados estava desenvolvida há muitos anos, muitas delas trabalham com isso desde a infância (YAMAOKA, 2019), ligado a profundo conhecimento do recurso, do ambiente onde está inserido e de seu comportamento. De fato, tais técnicas de secagem ao sol não parecem serem exclusivas da comunidade da Enseada da Baleia - por mais de uma vez pudermos ver procedimentos similares sendo executados também na comunidade do PereirinhaItacuruçá. Fora da Enseada da Baleia, porém, a técnica de secagem parece ser usada apenas para preparar peixes para consumo próprio, e os pescados destinados ao comercio são vendidos na maior parte tal como retirados do mar, enquanto a Enseada da Baleia usa tal técnica para agregar valor aos produtos da pesca antes de vende-los.

Afora o trabalho dos peixes, existe também ao menos em parte das comunidades (e.g - Pereirinha-Itacuruçá e Enseada da Baleia) o aproveitamento e confecção de artesanato com temas ligados a pesca e/ou usando de materiais trazidos pelo mar até as praias - tais como redes, petrechos de pesca e mesmo fragmentos de madeira, sobre o qual se realizam belas pinturas retratando o cotidiano caiçara (figuras 10, 11 e 12). 
Caderno de Geografia (2022) v.32, n.68

ISSN 2318-2962

DOI 10.5752/p.2318-2962.2022v32n.68p.73

Evitando assim que estes materiais, muitas vezes provindos da pesca industrial, sigam presentes entre praias e mar, prejudicando animais e plantas marinhas.

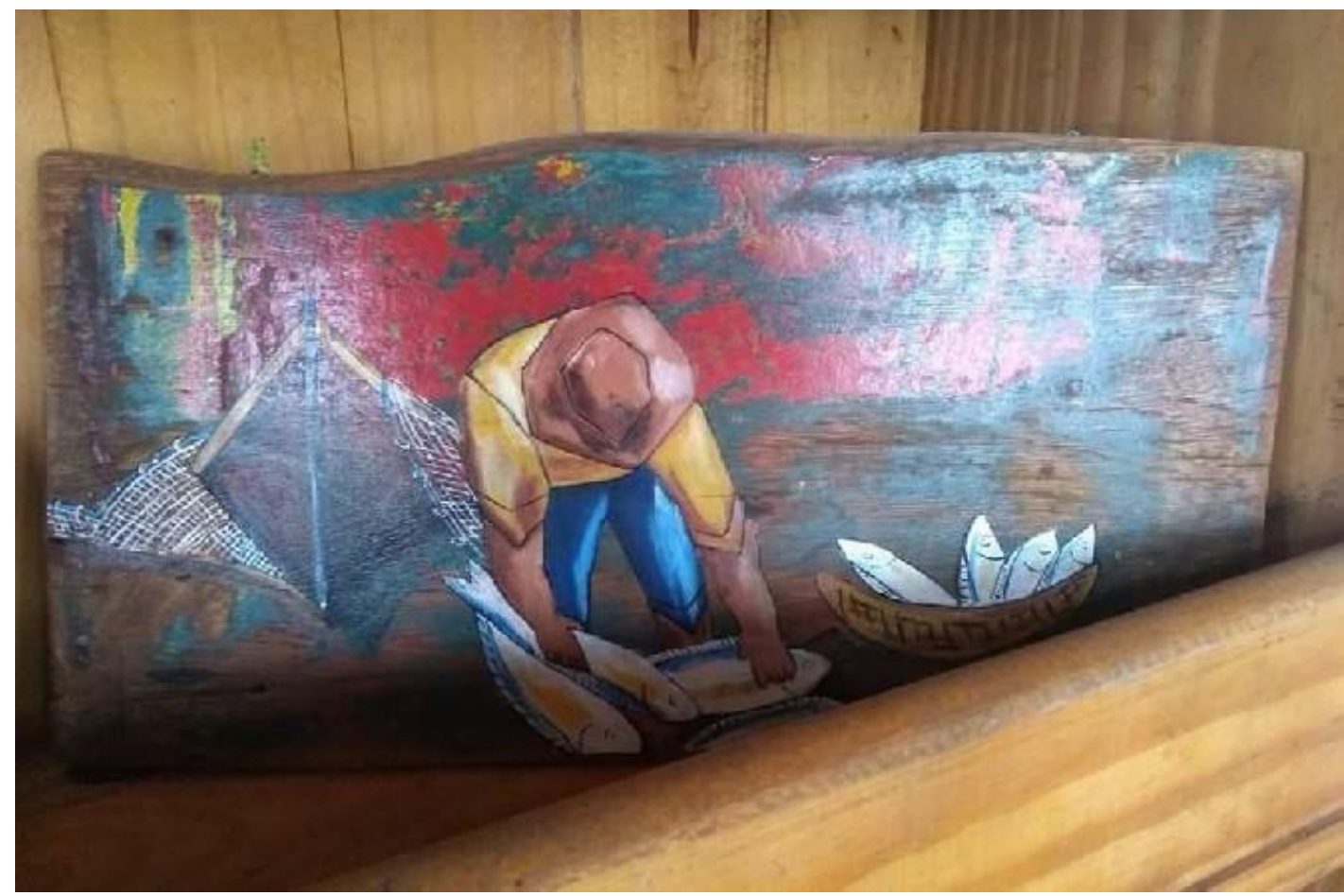

Figura 10 - Trabalho da artesã e caiçara moradora da Enseada da Baleia Tatiana Cardoso: pintura em madeira deixada pelo mar em praia próxima retratando atividade de pesca típica das comunidades locais.

Fonte: fotografia do primeiro autor, tirada em 2019.
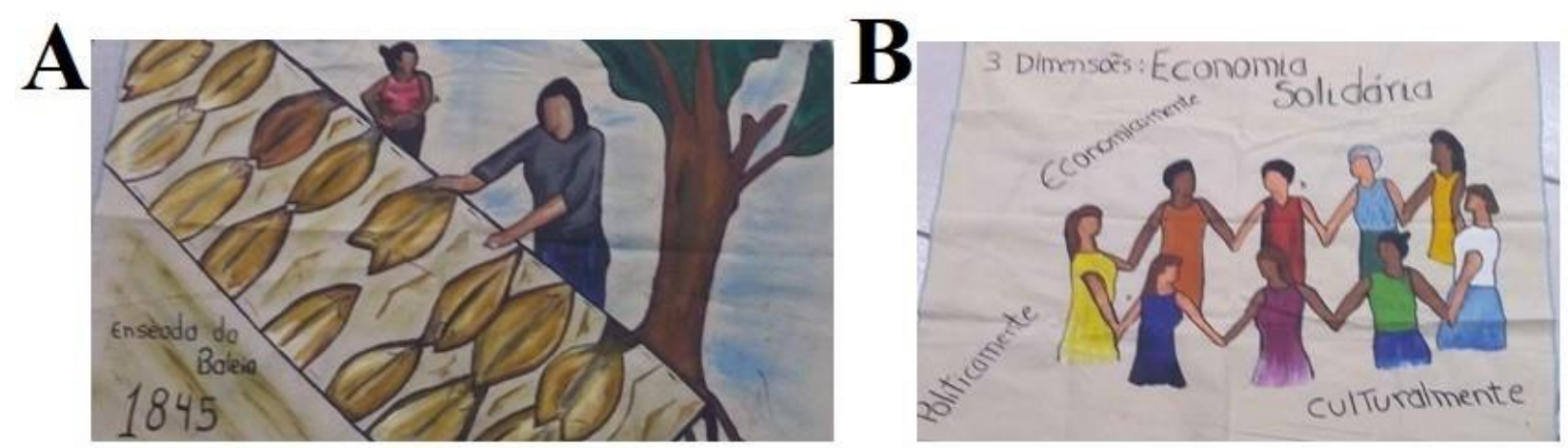

Figura 11 - Trabalhos em tecido da artesã Tatiana Cardoso, caiçara da Enseda da Baleia: A - retratando práticas tradicionais de secagem dos peixes, remetendo-as ao tempo de fundação da comunidade (1845); B - representação sobre os processos recentes de reorganização da comunidade.

Fonte: fotografias do primeiro autor, tiradas em 2019 


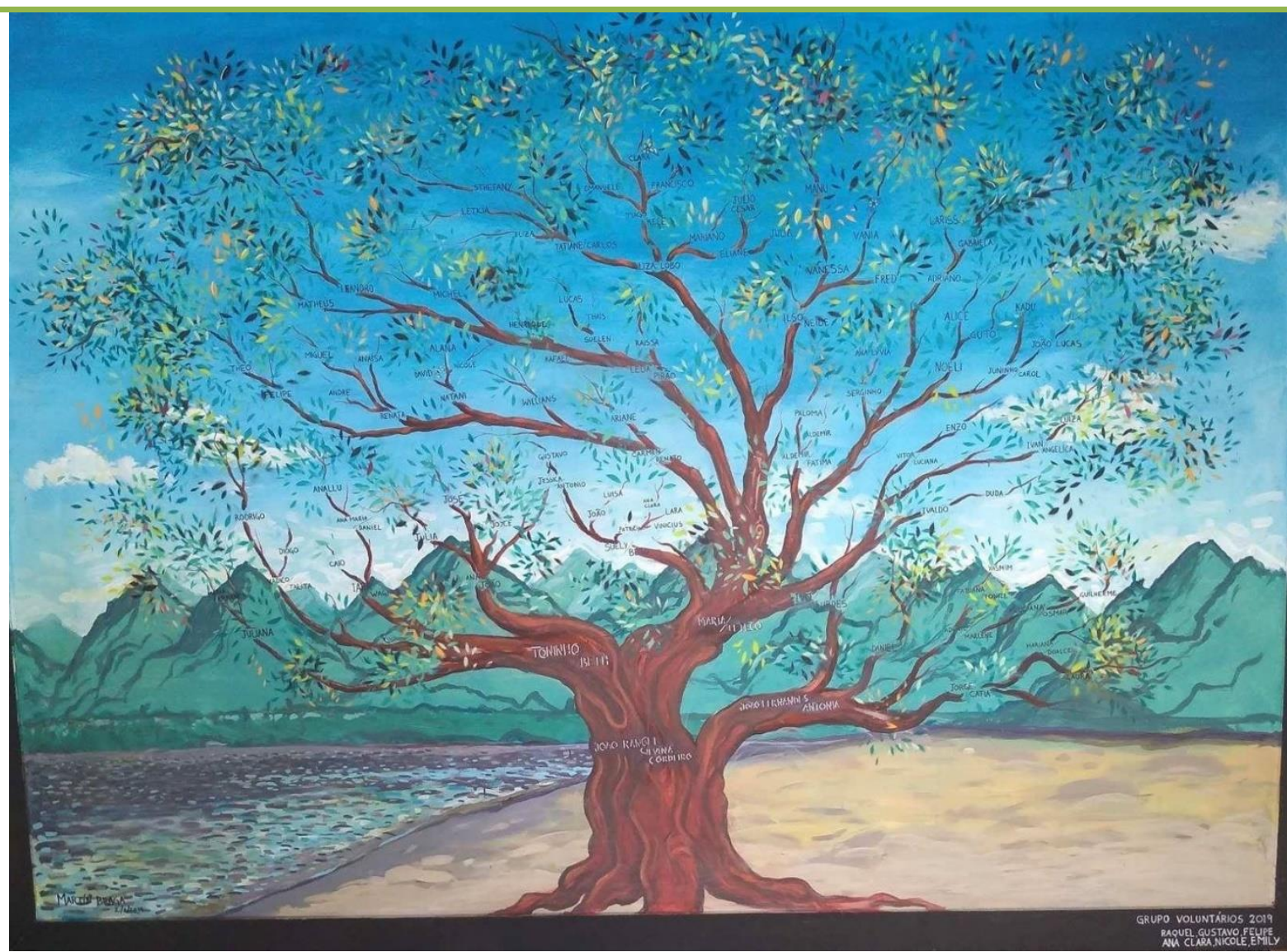

Figura 12 - fotografia de painel preparado em conjunto pela comunidade do Pereirinha-Itacuruçá e por equipe de estagiários do voluntariado de verão de 2019 do PEIC, ilustrando os dois padrões dominantes de paisagens da llha (Planícies e Serranias), com a árvore em primeiro plano sendo também uma representação da árvore genealógica da comunidade, com casal de fundadores associados a base do tronco, e seus descendentes retratados nos galhos que se desmembram a partir dele.

Fonte: fotografia do primeiro autor, tirada em 2019.

\subsubsection{Oscilações na centralidade da pesca ao longo do tempo}

Afora as oscilações e continuidades dos tipos práticas pesqueiras, registram-se significativas modificações da centralidade exercidas pela pesca e dos seus produtos nos modos de vida e territorialidades locais. Tais mudanças, de acordo com as entrevistas, teriam contribuição tanto da percepção de diminuição de abundância de peixes no "Mar de Dentro" com o passar do tempo e ao surgimento de novas opções de sustento em complemento a pesca. Realçando-se as possibilidades advindas de parcela dos membros das comunidades constituírem-se funcionários do parque, e de auxiliares nos processos de pesquisas científicas que passaram a ser feitas com regularidade no local após a conversão em unidade de conservação. Destacando-se, ainda, a flexibilização da visitação a determinados segmentos da ilha a partir de 1998, ligada a atividades de 
turismo de base comunitária, que podem ser desempenhadas somente por moradores reconhecidos como tradicionais da Ilha do Cardoso ${ }^{1}$.

Deste conjunto de opções, o turismo é visto como envolvendo um maior número de membros das comunidades, e também agentes externos que estabelecem mediações diversas com as comunidades pesqueiras, para assim terem acesso facilitado a seus territórios, de acordo com as entrevistas realizadas e de contribuições anteriores, tal como as de Marinho (2013) e Silva (2014). O turismo comunitário na llha se dá a partir de serviços de receptivo, sejam eles quiosques, restaurantes, campings, pousadas, quartos em casa de família, transporte de embarcações e monitoria ambiental. Mostrando-se complementados por serviços de prestadores de serviços externos, como agências, operadoras e monitores ambientais não residentes na própria Ilha, mas com domicílio na cidade de Cananéia. De maneira similar, pequenos grupos (de quatro a oito pessoas) de apoio sazonal ao turismo nos meses de maior movimentação atuam nesta atividade, através de estagiários voluntários selecionados pela equipe gestora do Parque, que por vezes participam do dia-a-dia e atividades das comunidades nestes momentos (figura 12). Podendo ser distinguido, inicialmente, de acordo com as entrevistas realizadas, o turismo recreativo, concentrado nos meses de verão, e os de educação ambiental, composto majoritariamente por escolas privadas de nível fundamental e médio vindas de grandes cidades no entorno do Vale do Ribeira, como São Paulo e Curitiba. Incluindo, ainda, escolas públicas da própria cidade de Cananéia e do Vale do Ribeira, por meio do programa denominado "Cananéia Tem Parque".

As entrevistas realizadas apontam uma percepção de uma incorporação heterogênea do turismo ao longo do tempo e dos distintos conjuntos de comunidades, e mesmo heterogeneidades internas ao longo dos territórios de cada uma delas, conforme detalhado no material suplementar 2. Em parte das comunidades, o turismo é percebido como passando a ter uma centralidade maior que a pesca para o sustento das famílias; em outras é visto como ocupando posição intermediária, ou mesmo, ainda, visto como incipiente ou pouco presente. Tais distintos padrões de modificações da centralidade da pesca artesanal nos modos de vida dos diferentes grupos das comunidades da Ilha ao

\footnotetext{
${ }^{1}$ Segundo o Programa de Interação Sócio-Ambiental, do Plano de Manejo - Fase 2 do Parque Estadual da Ilha do Cardoso o morador tradicional deve apresentar as "seguintes características":

- Chefe da família, deve estar há, no mínimo, 3 gerações na llha do Cardoso;

- Desenvolve atividades de baixa interferência no meio ambiente: pequena escala baseada no uso dos recursos renováveis;

- Tem conhecimento e domínio das técnicas tradicionais (pesca, agricultura e construção) (GOVERNO DO ESTADO DE SÃO PAULO, 2001, p. 111)
} 
longo do tempo após a conversão da llha em unidade de conservação lembram, em parte, os apontamentos de Candido (1965) ao abordar populações tradicionais caipiras do interior de São Paulo. Na medida em que o referido autor aponta que os membros de populações tradicionais que preservaram seus modos de vida e são tardiamente expostos as possibilidades vindas de um conjunto externo urbano-industrial do qual permaneceram longamente relativamente isoladas, desenvolvem três tipos de reações: 1 - os que negam quase que por completo os novos elementos vindos do complexo urbano-industrial e buscam vincular-se exclusivamente as práticas tradicionais; 2 - os que buscam com intensidade as novas perspectivas e deixam em segundo plano suas práticas tradicionais; 3 - os que buscam incorporar criteriosamente os novos elementos, de maneira a não prejudicar a essência de suas estratégias de vivência anteriores.

Muitos dos entrevistados relatam, ainda, que a renda provinda do turismo é hoje tida como superior à vinda das práticas pesqueiras, em especial pela percepção de aumento do fluxo turístico ao longo dos anos, e de diminuição da abundância de pescados no "Mar de Dentro". Mostrando-se nisso semelhante ao registrado por Capellesso e Cazella (2011) em comunidades de pescadores artesanais no litoral de Santa Catarina, e por Ramires et al. (2007) em llha Bela. A percepção da desigual incorporação nas diferentes comunidades das práticas de turismo comunitário é um fator realçado como importante em diferenciar suas estratégias de sobrevivência. Reforçam, ainda, que o dinheiro tem hoje um papel mais importante no modo de vida dos caiçaras atuais (e.g - maior aquisição de alimentação fora os pescados, de equipamentos domésticos, e barcos motorizados) do que no passado, na medida em que a manutenção integral da prática de obter do próprio meio natural uma parte dos itens necessários para suas necessidades é dificultada por restrições decorrentes da conversão de seus territórios em unidade de conservação.

Vários entrevistados ressaltam a importância da pesca não só como uma prática econômica, mas também enxergam nela um elemento importante para manutenção da própria identidade e dos laços sociais das comunidades, reforçando seu pertencimento a elas e sua ligação com seus respectivos territórios. De maneira que também enxergam a pesca como uma atividade responsável por perfazer sua mediação entre suas vidas, e as terras emersas e águas circundantes de seus territórios. Coerentes, assim, com apontamentos como os de Maldonado (1988 e 1993), Diegues (2000 e 2004) e Da Silva (2015) sobre as práticas pesqueiras artesanais e o conjunto de aspectos identitários nelas envolvidos, inclusive o papel importante na pesca na consolidação do território, e da 
territorialidade das comunidades pesqueiras. Mostrando, ainda, a pesca não apenas ligada a uma importância como uma questão produtiva, mas como construtora de sociedade (Da Silva, 2015), e com a integração a seus territórios com as terras e das águas em que inserem-se. De maneira que os citados entrevistados mostram, assim, preocupações pela percepção da diminuição da centralidade da pesca em uma parcela dos territórios da llha, pois interpretam que isto poderia levar a um enfraquecimento deste conjunto de elementos de coesão social e territorial que relacionam as práticas pesqueiras artesanais.

\section{CONSIDERAÇÕES FINAIS}

As interações entre o relevo, as águas e modos de vida vinculados aos territórios e territorialidades das comunidades caiçaras da llha do Cardoso caracterizam-se por uma mescla de oscilações e de permanências ao longo do tempo. Partindo dos distintos potenciais e restrições elencados pelo modo de vida caiçara como vinculados aos principais quadros naturais da llha, nota-se que restrições legais vinculadas a normatização da llha como unidade de conservação a partir dos anos 60 do século $\mathrm{XX}$ contribuíram para uma mudança das áreas preferenciais para atividades das comunidades locais. Houve a supressão do uso das bases das Serranias, mais propícias à agricultura (que passou a ser restringida após a normatização como unidade de conservação), e uma permanência restrita nas orlas litorâneas das Planícies Diversificadas, mais propícias a pesca.

Registrou-se que foram escolhidos segmentos específicos das Planícies para a instalação das comunidades, em áreas de transição entre diferentes subunidades de relevo, de maneira que situem-se em áreas fora dos segmentos mais intensamente visados por forças destrutivas da natureza (e.g - enchentes) associadas a ação das águas e ventos circundantes por ocasião da ocorrência de grandes tempestades. Simultaneamente, os locais escolhidos possibilitavam acesso rápido a essas mesmas águas circundantes, fundamentais para a prática da pesca e circulação pelos territórios locais. Igualmente, as águas circundantes mostram-se segmentadas em diferentes conjuntos pelos membros das comunidades - cada qual deles vistos como ligados a riscos e potenciais distintos para seus modos de vida. Tal segmentação feita pelas comunidades locais contribuiu para reservarem o uso em cada um dos conjuntos de águas ("Mar de Dentro", e "Mar de Fora") de específicas práticas e técnicas de navegação e pesca. 
Caracterizou-se, ainda, o aumento das centralidades da prática pesqueira no uso dos territórios por parte das comunidades após a normatização da llha e de seus territórios tradicionais em unidade de conservação, bem como modificações de uma parte das técnicas pesqueiras para adapta-las as restrições do novo contexto.

Elencou-se também, num segundo momento - após a flexibilização de algumas das restrições ligadas a previamente citada normatização como unidade de conservação alterações da centralidade das práticas pesqueiras em meio as territorialidades locais, e um aumento da importância do turismo (incorporado de maneira heterogênea no tempo e nos territórios locais) para o sustento das famílias caiçaras. Aponta-se que o elevado grau de preservação ambiental local - mantido com contribuição das interações que comunidades locais praticam com o relevo e águas - se tornou algo raro no contexto do Centro-Sul do Brasil, o que contribui para um crescente interesse de atores externos pelo turismo e pesca na área, bem como também sinaliza a perspectiva de aumento de pressões pelo uso e controle dos recursos naturais da llha. Caracteriza-se, assim, que a complexa e dinâmica trajetória de usos das terras e águas locais reflete, em parte, as interações tardias de comunidades e territórios tradicionais antes relativamente isolados com um conjunto externo densamente urbanizado e industrializado, que foi mais cedo incorporado ao meio técnico majoritário atual.

\section{AGRADECIMENTOS}

Agradecemos aos moradores das comunidades da llha do Cardoso pela boa vontade, confiança e apoio com relação aos trabalhos de pesquisa dos autores deste artigo. Agradecemos às equipes do Parque Estadual da llha do Cardoso (PEIC) e do Instituto de Pesquisas Cananéia (IPEC) pelo apoio dado para a realização de parte das atividades das pesquisas sintetizadas neste artigo. Igualmente, agradece-se ao apoio e autorização do Instituto Florestal e da Fundação Florestal para a realização de uma parte das atividades das pesquisas aqui apresentadas. O primeiro autor é grato por ter recebido uma bolsa de mestrado da CAPES e de doutorado do CNPQ (308772/2018-0), e a segunda autora é grata por ter recebido bolsas da CAPES e Fundação Araucária.

\section{REFERÊNCIAS}

ACEVEDO-GUTIÉRREZ, A.; STIENESSEN, S. C. Bottlenose dolphin (Tursiops truncatus) increase number of whistles when feeding. Aquatic Mammals, v. 30, p. 357-362, 2004. 
ADAMS, C. As populações caiçaras e o mito do bom selvagem: a necessidade de uma abordagem interdisciplinar. Revista de antropologia, São Paulo, v. 43, n. 1, p. 145-182, 2000.

ALMEIDA, A. P. Memória histórica da Ilha do Cardoso. In: DIEGUES, A. C. Enciclopedia Caiçara: História e Memória Caiçara - Volume IV. São Paulo: Hucitec NUPAUB/CEC, 2005, p. 61-75.

BASTIDE, R. Brasil, terra de contrastes. São Paulo: Difusão Europeia do Livro, 1964. $58 p$.

BRAGA, R. Raízes da questão regional no estado de São Paulo. Geografia (Rio Claro), v. 24, n. 3, p. 43-67, 1999.

CANDIDO, A. Os parceiros do Rio Bonito: estudo sobre o caipira paulista e a transformação dos seus meios de vida. 11. ed. Rio de Janeiro: Ouro sobre azul, 1965. $336 p$.

CAPELLESSO, A. J.; CAZELLA, A. Pesca artesanal entre crise econômica e problemas socioambientais: estudo de caso nos municípios de Garopaba e Imbituba (SC). Ambiente e sociedade, v. 14, n. 2, p. 15-33, 2011.

CARVALHO, M. C. P.; SCHMITT, A. Relatório técnico-científico para identificação de famílias tradicionais presentes no Parque Estadual da Ilha do Cardoso. São Paulo: . Relatório técnico-científico. 2012. 307p.

CHAVES, P. T.; ROBERT, M. C. Embarcações, Artes e Procedimentos da Pesca Artesanal no Litoral Sul do Estado do Paraná, Brasil. Atlântica, Rio Grande, v. 25, n. 1, p. 53-59, 2003.

CHELIZ, P. M. Ilha do Cardoso: Contribuições para compartimentação do relevo. 2015. 236 f. Dissertação (Mestrado em Geografia) - Instituto de Geociências, Universidade Estadual de Campinas, Campinas, 2015.

CHELIZ, P. M.; SOUSA, C. R.; RODRIGUES E. N.; NUNES, M.; OLIVEIRA, R. C. Apontamentos sobre oscilações geomorfológicas e impactos ambientais na ruptura da llha do Cardoso, e formação de nova barra do Canal de Ararapira (Cananéia-SP). In: SIMPÓSIO BRASILEIRO DE GEOMORFOLOGIA. 12., 2019, Fortaleza, Anais... Fortaleza, 2019.

CHELIZ, P. M.; OLIVEIRA, R. C. Geomorfologia e estrutura superficial da paisagem de zonas costeiras rochosas: um estudo de caso na Ilha do Cardoso (Litoral Sul de São Paulo). Revista Brasileira de Geografia Física, v. 14, n. 6, p. 3667-3694, 2021.

COELHO, K. O GPS perde pra mim de longe! Cartoprática e políticas caiçaras em navegação no Mar de Dentro. Revista Entrerios, v. 2, n. 1, p. 24-40, 2019.

CUBAS, W. Observação Sobre a Pesca com Cerco-Fixo na Região de Cananeia, SP. 2018. (Monografia) - Universidade Estadual Júlio de Mesquita, 2018. 
DA SILVA, L. A. Com vento a lagoa vira mar: uma etnoarqueologia da pesca no litoral norte do RS. Boletim do Museu do Pará Emilio Goedi, Ciência Humanas, Belém, v. 10, n. 2, p. 537-547, 2015.

DAURA-JORGE, F. G.; CANTOR, M.; INGRAM, S. N.; LUSSEAUND, D.; SIMÕESLOPES, P. C. The structure of a bottlenose dolphin society is coupled to a unique foraging cooperation with artisanal fishermen. Biology letters, v. 8, n. 5, p. 702-705, 2012.

DIEGUES, A. llhas e mares: simbolismo e imaginário. São Paulo: HUCITEC, 1998. 298p.

DIEGUES, A. C. (Org.) A imagem das águas. São Paulo: Hucitec, 2000. 210p.

DIEGUES, A. A pesca construindo sociedades. São Paulo: NUPABUSP, 2004.

DIEGUES, A. C. Esboço de história ecológica e social caiçara. In: DIEGUES, A. C. Enciclopedia Caiçara: História e Memória Caiçara - Volume IV. São Paulo: Hucitec, 2005, p. 273-319.

GADELHA, C. Proibido trabalhar: problema socioambiental dos filhos da llha do Cardoso/SP. 2018. 305 f. Dissertação (Mestrado em Antropologia Social) - Instituto de Filosofia e Ciências Humanas, Universidade Estadual de Campinas, Campinas, 2008.

GONÇALVEZ, J. O. Análise comparativa dos planos de manejo em unidades de conservação do Brasil e do Uruguai. Tese de doutorado. 2021. (Tese) - Universidad de la Republica, Montevideu, 2021.

GOVERNO DO ESTADO DE SÃO PAULO; SMA - Secretaria do Meio Ambiente. Plano de Manejo - Fase 2 /Parque Estadual da Ilha do Cardoso. São Paulo, 2001. Disponível em: $\quad<$ http://arquivos.ambiente.sp.gov.br/fundacaoflorestal/2012/01/PlanoManejoPEIC.pdf>. Acesso em: 11 nov. 2016.

JOHANNES, R. E. Marine conservation in relation to traditional life-styles of tropical artisanal fishermen. Environmentalist, v. 4, p 30-35.

MALDONADO, S. Antropologia Marítima, Comunicação e Cultura. Cadernos Paraibanos de Antropologia e Sociologia, v. 4, p. 267-279, 1988

MALDONADO, S. Mestres e Mares: espaço e indivisão na pesca marítima. São Paulo: Aannablume, 1993. 194p.

MARINHO, M. Territorialidade e Governança em Áreas Protegidas: $O$ caso da comunidade do Marujá, no Parque Estadual da llha do Cardoso (Cananeia, SP). 2013. Tese - Universidade de São Paulo, São Paulo, 2013.

MENDONÇA, A. A llha do Cardoso: o Parque Estadual e os Moradores. 1999.

MENDONÇA, J. T.; KATSURAGAWA, M. Caracterização da pesca artesanal no complexo estuarino-lagunar de Cananéia-Iguape, Estado de São Paulo, Brasil (1995-1996). Acta Scientiarum. Biological Sciences, v. 23, p. 535-547, 2008. 
MOURÃO, F. A. Os pescadores do Litoral Sul de São Paulo: um estudo de sociologia diferencial. São Paulo: Hucitec/NUPAUB/CEC, 2003. 264p.

MOURÃO, J.; NORDI, N. Ethnoichthyology of artisanal fishermen from the estuary of Mamanguape River, Paraíba, Brazil. Boletim do Instituto de Pesca, v. 29, n. 1, p. 9-17, 2018.

NABHAN, N. Dois mares que se juntam e a coletividade que aflora: meio ambiente e identidade caiçara na comunidade da Nova Enseada, Parque Estadual da llha do Cardoso-SP. 2021. Dissertação - Universidade Federal de São Carlos, São Carlos, 2021.

NUPAUB - NÚCLEO DE APOIO À PESQUISA SOBRE POPULAÇÕES HUMANAS EM ÁREAS ÚMIDAS DO BRASIL. Laudo Técnico de avaliação da área de reassentamento da comunidade de Enseada da Baleia sob os aspectos antropológicos, ambientais e segurança geológica diante do processo erosivo na Ilha do Cardoso/Cananéia-SP. São Paulo, 2016. 94p.

RAMIRES, M.; MOLINA, S. M. G.; HANAZAKI, N. Etnoecologia caiçara: o conhecimento dos pescadores artesanais sobre aspectos ecológicos da pesca. Biotemas, Florianópolis, v. 20, n. 1, p. 101-113, 2007.

RAMIRES, M.; CLAUZET, M.; ROTUNDO, M.; BEGOSSI, A. Artisanal fishing and fishermen of Ilhabela - São Paulo State - Brazil. Boletim Do Instituto De Pesca, v. 38, n. 3, p. 231-246, 2018.

SANTOS, M. A Natureza do Espaço: Técnica, Razão e Emoção. 3. Ed. São Paulo: Edusp, 2003. 392p.

SILVA, J. L. Os Desdobramentos e Conflitos da Criação do Parque Estadual Ilha do Cardoso sob a Ótica do Modelo GTP (Geossistema - Território- Paisagem). 2014. Dissertação - Universidade Estadual Júlio de Mesquita, Presidente Prudente, 2014.

VIEGAS, M. C.; MONIZ, A. B.; SANTOS, P. T. Artisanal Fishermen Contribution for the Integrated and Sustainable Coastal Management - Application of Strategic SWOT Analysis. Procedia - Social and Behavioral Sciences, v. 120, p. 257-267, 2014.

YAMAOKA, J. G.; NEVES, J.; CARDOSO, T.; DENARDIN, V. Economia solidária e contribuição tecnológica: mulheres artesãs da Enseada, comunidade tradicional caiçara de Cananéia/SP. Disponível em: <http://www.conpes.ufscar.br>. Acesso em: 27 mai. 2019.

ZEDEÑO, M. N.; STOFFLE, R. W. Landmark and landscape: A contextual approach to the management of American Indian resources. Culture and Agriculture, v. 9, n. 3, p. 123129, 1997.

ZEDEÑO, M. N. The archeology of Territory and Territoriality. In: DAVID, B; THOMAS, J. Handbook of Landscape Archaeology. Walnut Creek. 2008. 